\title{
Income distribution in Argentina, 1974-2000
}

\section{Oscar Altimir}

ECLAC, United Nations, oaltimir@eclac.cl

Luis Beccaria

Universidad Nacional de General Sarmiento, Buenos Aires, Argentina, lbeccari@ungs.edu.ar

Martín González Rozada

Universidad Torcuato Di Tella, Buenos Aires, Argentina,

mrozada@utdt.edu.ar
Over the last quarter-century, the distribution of income in Argentina has deteriorated steadily. This article utilizes microsimulation analysis to decompose the impact that labour changes have had on the distribution of family income. In the $1970 \mathrm{~s}$, the deterioration was due to real reduction and relative dispersion of wages; in the1980s, it was linked to growing unemployment resulting from successive crises; in the1990s, under the new economic order, the deterioration continued as a result of the unemployment generated by the restructuring of production and the increase in labour force participation, coupled, in the last phase, with greater inequality in wage levels. The article concludes that the new economic model involves, beyond currency appreciation and the ultimate collapse of the macroeconomic regime, a lower employment elasticity of growth -thereby generating more structural unemployment- and a larger wage gap between workers at different skill levels. 


\section{I}

\section{The evolution of income distribution}

Dynamic analysis of income distribution is highly conditioned by the availability of microdata from comparable surveys. In the case of Argentina, such analysis is limited by the availability of data from the Permanent Household Survey (Encuesta Permanente de Hogares (EPH)). For 1974 and for the years since 1980 there are data for Greater Buenos Aires, but only after 1990 did comparable data become available for ten urban agglomerations in the country's interior. ${ }^{1}$

However, it is possible to take a longer-term retrospective view, looking only at the probable evolution of inequality, based on measurements derived from various sources -and therefore not strictly comparable- prior to 1974 . This has been done elsewhere (Altimir, 1986; Altimir and Beccaria, 2000a; Altimir and Beccaria, 2001), and the results indicate that: i) between 1953 and 1961, with a yearly per capita growth rate of over $2 \%$, inequality among households at the national level appears to have increased by only $5 \%$ as measured by the Gini coefficient, although the increase among non-farming households was $10 \%$; and ii) inequality in Greater Buenos Aires (and, presumably, in all urban areas) seems to have remained unchanged throughout the 1960 s and the early 1970 s up to $1974 .^{2}$

Our analysis of the evolution of income distribution encompasses the period from 1974 to 2000 and is based on data from the EPH. ${ }^{3}$ It compares income distribution

$\square$ We are grateful for the comments of José Antonio Ocampo and Juan V. Sourrouille, who, however, bear no responsibility for the final content of this article.

${ }^{1}$ The twenty-eight urban agglomerations now covered by the EPH have been added gradually over the years by the National Institute of Statistics and Censuses (INDEC), and not all of them have been included every year.

${ }^{2}$ However, if the data from the surveys are adjusted for the effect of underreporting of income, the concentration may have tended to increase moderately between 1970 and 1974/1975 (Altimir, 1986). As the original survey data show a virtually constant concentration between 1970 and 1975, it can be concluded that despite the notable growth in real wages in the latter year (as seen in figure 4 below), income distribution in that same year (in which economic activity increased markedly) did not differ greatly from that of earlier years.

${ }^{3}$ This does not mean that we have overlooked the possible underestimation and omissions of income in the EPH or the effect that they may have had on the concentration of income; in that in the peak years of each period in which a particular macroeconomic regime and policy prevailed; these were the years in which the level of economic activity reached a relative maximum and, therefore, the economy was closest to its productive frontier ${ }^{4}$ (table 1). The reason for selecting periods in this manner, in addition to considerations relating to the availability of data, was to reduce the influence of cyclical disturbances on the determination of distributive results in order to identify as clearly as possible the trends and structural changes that have shaped income distribution in this quarter-century.

If only the years selected according to the stated criterion are considered, a steady worsening trend in the distribution of household income (and therefore well-being) throughout the quarter-century is noted, resulting in an exacerbation of inequality as evidenced by the rise in the Gini coefficient from 0.36 in 1974 to 0.51 in 2000 (figure 1). Moreover, this trend was compounded by temporary deteriorations during periods of crisis: the hyperinflation of the late 1980s, the "tequila episode" and the most recent recession, which continues today. During the period 1991/1993, in contrast, the level of inequality was below the indicated trend.

However, income distribution among employed individuals (which is more reflective of wages generated in the productive apparatus) evolved somewhat differently: after worsening in 1974/1980 -even more sharply than income distribution among householdsthe trend (marked in our interpretation by distributive situations closest to the structural distribution) remained relatively stable until $1994^{5}$ and then rose again, with the Gini coefficient increasing 3\% by 1997.

connection, see Altimir (1986) and Altimir and Beccaria (2000a). It is assumed, however, that the underestimation and omissions have not changed significantly, meaning that they have not increased or decreased the relative difference between measured and actual inequality.

${ }^{4}$ This was not the case, however, in 1990, which was chosen because it was the last year prior to the change of regime, nor was it the case in 2000, during which the recession that had begun in 1998 continued; however, it is the last year for which data were available. ${ }^{5}$ The $3.8 \%$ decrease, between 1980 and 1986, in the value of the Gini coefficient of this distribution is statistically significant at $95 \%$, based on the confidence intervals estimated by a bootstrapping

INCOME DISTRIBUTION IN ARGENTINA, 1974-2000 • OSCAR ALTIMIR, LUIS BECCARIA AND MARTIN GONZALEZ ROZADA 
TABLE 1

Argentina: macroeconomic framework for the observations of income distribution

\begin{tabular}{|c|c|c|c|c|c|c|c|c|c|c|}
\hline \multirow[t]{2}{*}{$\begin{array}{l}\text { Macroeconomi } \\
\text { periods }\end{array}$} & & \multirow[t]{2}{*}{$\begin{array}{c}\text { Date of } \\
\text { observation }\end{array}$} & \multirow{2}{*}{$\begin{array}{c}\text { Real per capita } \\
\text { mean income } \\
\text { of households, } \\
\text { Greater Buenos Aires }\end{array}$} & \multicolumn{2}{|c|}{$\begin{array}{c}\text { GDP level } \\
(1980=100)\end{array}$} & \multirow{2}{*}{$\begin{array}{c}\text { Urban } \\
\text { employment } \\
(1980=100)\end{array}$} & \multirow{2}{*}{$\begin{array}{c}\text { Urban } \\
\text { unemployment } \\
(\%)\end{array}$} & \multirow{2}{*}{$\begin{array}{l}\text { Monthly } \\
\text { inflation } \\
\quad(\%)\end{array}$} & \multirow{2}{*}{\multicolumn{2}{|c|}{$\begin{array}{l}\begin{array}{c}\text { Real wage } \quad \text { Real } \\
\text { exchange rate }\end{array} \\
(1980=100)\end{array}$}} \\
\hline & & & & $\overline{\text { Total }}$ & Non-farm & & & & & \\
\hline 1973-1975 & $\begin{array}{l}\text { Populist } \\
\text { stablilization }\end{array}$ & III 1974 & 110.1 & 90.0 & 89.2 & 92.8 & 3.4 & 3.0 & 118.5 & 125.3 \\
\hline \multirow[t]{2}{*}{$1976-1980$} & $\begin{array}{l}\text { Orthodox } \\
\text { stabilization } \\
\text { with }\end{array}$ & & & & & & & & & \\
\hline & liberalization & III 1980 & 100.0 & 101.8 & 101.4 & 100.0 & 2.5 & 4.2 & 100.0 & 100.0 \\
\hline $1981-1984$ & $\begin{array}{l}\text { Chaotic } \\
\text { adjustment } \\
\text { and return } \\
\text { to populism }\end{array}$ & & & & & & & & & \\
\hline $1985-1986$ & $\begin{array}{l}\text { Transitory } \\
\text { stabilization }\end{array}$ & III 1986 & 91.7 & 99.7 & 98.7 & 108.5 & 5.2 & 7.6 & 92.6 & 268.2 \\
\hline \multirow[t]{2}{*}{ 1987-1990 } & Slide to & & & & & & & & & \\
\hline & hyperinflation & III 1990 & 62.8 & 91.2 & 97.4 & 114.8 & 6.2 & 13.9 & 62.9 & 168.7 \\
\hline \multirow[t]{4}{*}{$1991-2000$} & Stabilization & III 1991 & 72.7 & 100.5 & 99.4 & 118.8 & 6.0 & 1.9 & 70.0 & 124.5 \\
\hline & and new & III 1994 & 82.4 & 126.9 & 126.8 & 120.4 & 12.2 & 0.6 & 81.0 & 101.9 \\
\hline & economic & III 1997 & 81.0 & 141.5 & 142.1 & 129.1 & 13.7 & 0.3 & 75.4 & 105.1 \\
\hline & regime & III 2000 & 81.2 & 139.9 & 140.2 & & 14.7 & 0.1 & 78.4 & 113.3 \\
\hline
\end{tabular}

Source: Developed by the authors on the basis of data from ECLAC and the EPH.

FIGURE 1

\section{Argentina: income distribution among households} and individual income earners, 1974-2000

(Gini coefficients)

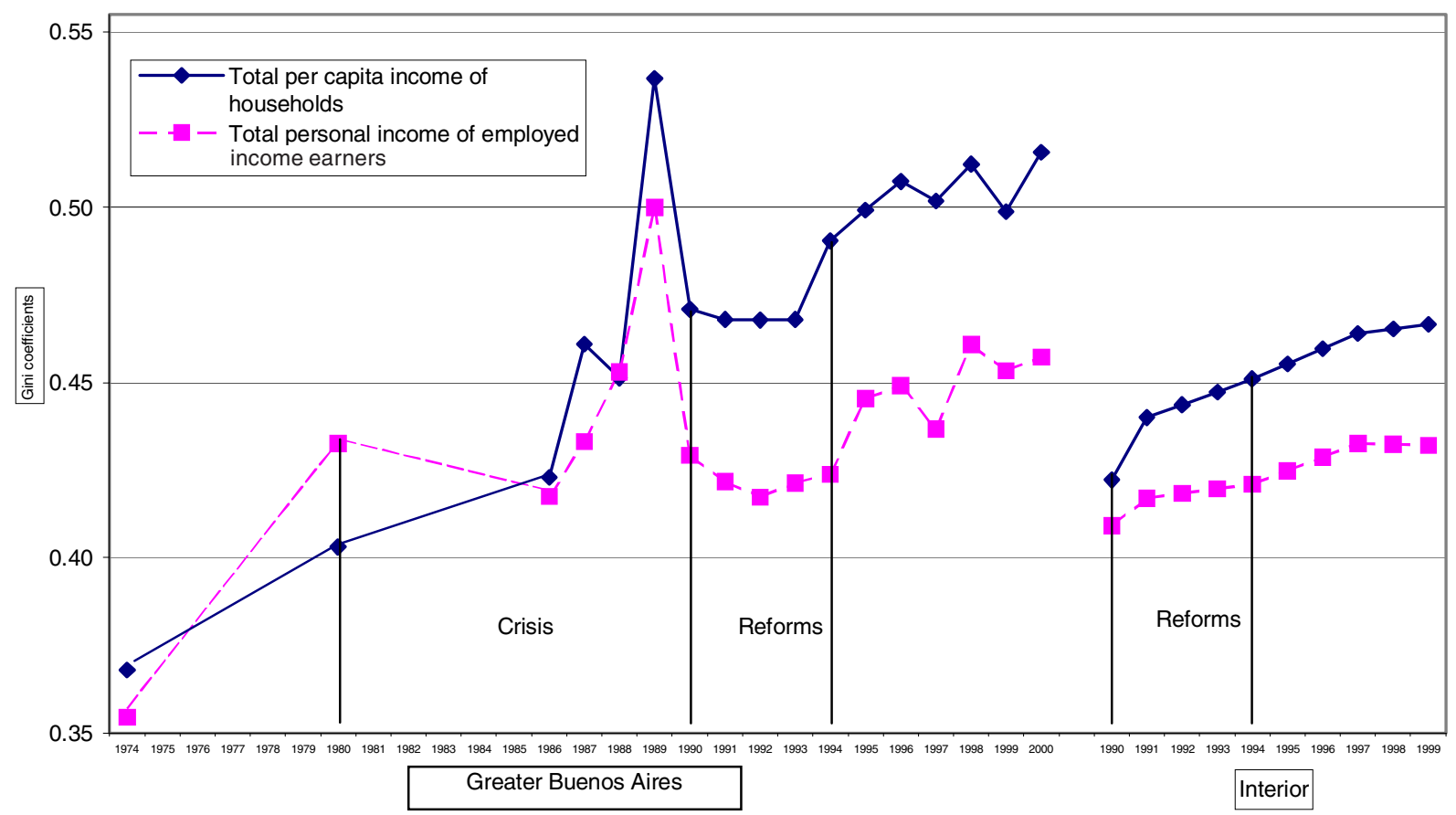

Source: Developed by the authors on the basis of data from the EPH. 
Subsequently, with the economy already in recession, inequality oscillated around a rising trend, and by 2000 the Gini coefficient was $4.7 \%$ higher than in 1997 , the last "normal" year from the perspective of economic activity (figure 1).

The contrast between the evolution of income distribution among households and employed individuals has been determined -as will be revealed in the analysis that follows- by changes in labourmarket participation and unemployment. The influence of these two factors, coupled with that of the structure of wages, on household income distribution is analysed by means of a microsimulation exercise.

\section{II}

\section{Real incomes}

\section{Deterioration by income deciles}

The evolution of the relative distribution of nominal household income described above also implies an unequal evolution in real terms. The real per capita mean income of households in Greater Buenos Aires showed a downward trend from 1974 to $1990 / 1991$ and then fluctuated around a level $20 \%$ below that of $1980^{9}$ (table 1). This evolution includes the loss of purchasing power due to the increase in the relative prices

procedure that made it possible to generate our alternatives. The differences between the Gini coefficient values for 1986, 1990 and 1994, on the other hand, did not exceed 3\% and are not statistically significant.

${ }^{6}$ The aggregate values of the Gini coefficient for the ten cities showed very little variation from this trend (figure 1).

${ }^{7}$ The urban agglomerations for which microdata from the EPH were available for the 1990s were Córdoba, Jujuy, La Plata, Mendoza, Neuquén, Rosario, Salta, Santa Rosa, Río Gallegos and Tucumán. ${ }^{8}$ The differences in the Gini coefficient values for the two domains were not statistically significant (around 1\%) for 1991, 1994 and 1997, but not in 1990, when the Gini coefficient of income distribution for the interior cities was $5 \%$ under that of Greater Buenos Aires. If 1990 is taken as the reference year, the inequality of personal income increased more than in the metropolitan area. ${ }^{9}$ The mean income for the whole set of urban areas (Greater Buenos Aires plus the ten cities of the interior) has suffered an equal or greater decline: both in 1991 and in 1994 it was around 8\% below the mean income of the metropolitan component; by 1999/2000 it had dropped to $10 \%$ below that level, with the resultant lag in the interior urban component.
The evolution of income inequality in the cities of the interior in the 1990s did not differ greatly from the pattern observed in Greater Buenos Aires, especially in the years for which the trend was analysed, ${ }^{6}$ during which the degree of concentration of personal income in the ten cities studied ${ }^{7}$ was very similar to that of the Buenos Aires metropolitan area. ${ }^{8}$ The inequality of family income in the interior also showed a similar pattern -though at lower Gini coefficient levels- to that observed in the distribution among metropolitan households, except that among households in the other cities the greatest worsening occurred in 1991, rather than 1994 (figure 1). applicable to household incomes stemming from the rise in the exchange rate beginning in 1990. ${ }^{10}$

If 1980 is taken as a basis for comparison (as in figure 2), ${ }^{11}$ the relative losses of real income between 1974 and that year diminished with income level, except in the lowest decile -in which the loss was similar to the average loss- and the top decile, which suffered hardly any loss. On the other hand, the loss in real terms between 1980 and $1986-8 \%$ on average- was more evenly distributed, although it was always smaller in the uppermost income quintile. The steep drop in incomes associated with the crisis and the hyperinflation of the late 1980s and early 1990s was quite generalized, and its effect on the middle and low income strata was almost neutral (especially in comparison to 1986); however, the loss of the top decile was smaller than the average. The partial recovery of incomes between 1990 and 1994 was also inequitable, growing with income

\footnotetext{
${ }^{10}$ The rise in prices of non-tradable goods was manifested in increases in the consumer price index (CPI) that were around 35\% higher than the evolution of the GDP implicit price index. This is the principal reason why real mean household income increased much less in the 1990s than per capita national income (table 1).

${ }^{11}$ The year 1974 is not a suitable basis of comparison for the entire period, given that the highest maximum real wage for the period 1960/2000 was achieved in that year (see figure 4 below), in a macroeconomic context that proved unsustainable. In contrast, the level of real wages registered in 1980 had already been reached by the mid-1960s and early 1970s, and wages then returned to that level in the mid-1980s.
} 
FIGURE 2

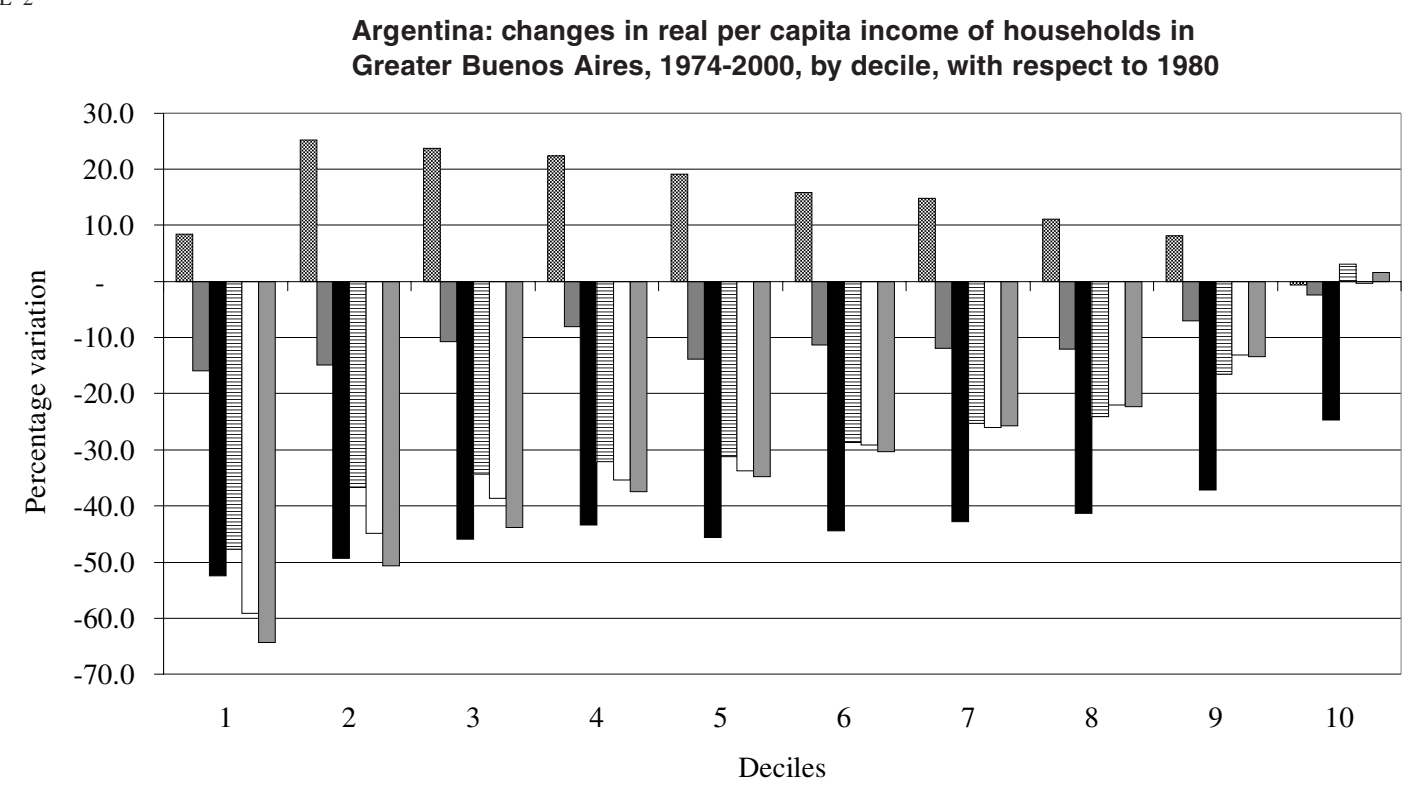

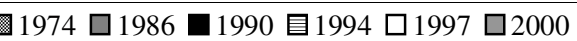

Source: Developed by the authors on the basis of data from the EPH.

level, to the point that real income in the top decile rose to a higher level than in 1980. The subsequent evolution of real incomes was clearly regressive. The incomes of the lowest $60 \%$ of households deteriorated -in a manner inversely proportional to their respective levels- while the real incomes of the top three deciles improved. Hence, the distributive situation at the end of the twentieth century exhibited, in real terms, a notable regression with respect to 1980 (figure 2).

\section{Poverty}

The incidence of poverty in Greater Buenos Aires ${ }^{12}$ rose throughout the period, over and above the jump it registered with the hyperinflation of 1989/1990. In 1974 fewer than 5\% of households were poor, in 1980 the figure was closer to 6\%, in 1986 it exceeded 9\%, and in 1990 it climbed to $25 \%$ of households, later falling to under $15 \%$ in 1994 and then rising again to $21 \%$ in the year 2000 .

If, in order to identify the poor, income distribution is partitioned by a poverty line that remains the same

${ }^{12}$ Until very recently, there was a single official poverty line for all of Greater Buenos Aires, and official estimates of the incidence of poverty in Greater Buenos Aires began to be published only in 1986. The figures for 1974 and 1980 therefore come from Altimir and Beccaria (1998) and were obtained by replicating the procedures utilized for calculating official estimates. in real terms, the incidence of poverty varies with the real income of the set of households and their distribution by income levels. Table 2 decomposes the changes in poverty incidence in the various subperiods. ${ }^{13}$

During the decade of crisis, two-thirds of the considerable growth in absolute poverty was due to the fall of real household income associated with the recession and the deterioration of the terms of trade. ${ }^{14}$ However, one-third of the increase in poverty incidence was the result of changes in income distribution. The recovery and expansion of the economy between 1991 and 1994 had an effect that favoured poverty reduction, but it was cancelled out completely by the unfavourable impact of the distributive changes. Between 1994 and 1997, the combination of declining real income and worsening income distribution prompted a new increase

\footnotetext{
${ }^{13} \mathrm{P}(0)$, one of the Foster-Greer-Thorbecke poverty indicators, which measures the proportion of poor households out of total households. The magnitude of the change in poverty incidence follows, but does not coincide exactly with, the trend of official estimates because those figures are based on EPH income data adjusted for underestimation (Altimir y Beccaria, 1998).

${ }^{14}$ This occurred towards the end of the decade as a result of the effect of currency devaluation on the price of tradable goods in the CPI.
} 
TABLE 2

Greater Buenos Aires: Decomposition of the change in incidence of absolute poverty

(Percentage points)

\begin{tabular}{lccc}
\hline Period & Total change & Effect of mean income & Effect of distribution \\
\hline $1974-1980$ & $\ldots$ & 1.5 & -1.4 \\
$1980-1986$ & 3.2 & 2.1 & 0.8 \\
$1986-1991$ & 2.7 & 1.4 & 1.8 \\
$1991-1994$ & 0.4 & -2.3 & 0.1 \\
$1994-1997$ & 4.1 & 2.6 & -0.5 \\
$1997-2000$ & 1.4 & -0.6 & 0.4 \\
\hline
\end{tabular}

Source: Developed by the authors on the basis of data from the EPH.

in the incidence of absolute poverty. In contrast, in the years that followed, up to 2000 , the ongoing deterioration in income distribution alone was responsible for the rise in poverty (table 2 ).

\section{III}

\section{Labour market trends}

The labour force grew slowly in the 1970s and 1980s, but it underwent rapid expansion in the 1990s. The urban activity rate trended downward throughout the $1970 \mathrm{~s},{ }^{15}$ reaching $38.5 \%$ in 1980 . In the first half of the $1980 \mathrm{~s}$, the participation rate stagnated but then rose steadily in the second half of the decade, in a context of income reduction and instability. Thereafter, the aggregate activity rate in urban areas rose from $39.5 \%$ in 1991 to more than $42 \%$ of the total population as of 1997 (figure 3). ${ }^{16}$

The rate of job creation -in both the formal and informal sector- in the 1980 s was not sufficient even to match the moderate rate of growth in supply, and the result in the 1990s was a notable deficiency of labour absorption, even at times when economic activity was growing rapidly. Consequently, urban unemployment

\footnotetext{
${ }^{15}$ During the first half of the decade this was a result of the income effect associated with the wage hike. During the second half of the decade, in contrast, the decline was due to the substitution effect -linked to the reduction in wages- and discouragement over the creation of fewer jobs in the formal sector (Altimir and Beccaria, 2000b).

${ }^{16}$ This considerable increase in the overall urban rate was due almost exclusively to the increase registered in Greater Buenos Aires, where the rate of labour market participation climbed from $40.9 \%$ to more than $45 \%$, largely due to the growth of female participation (Altimir and Beccaria, 2000b).
}

rose by three percentage points during the 1980s, climbing from around 5\% in the early years to around $6 \%$ in $1985 / 1988$ and to over $7 \%$ with the onset of the hyperinflationary crisis. With the arrival of reforms and stability, unemployment soared: in three years (between 1992 and 1995/1996, in the midst of the adjustment period following the tequila crisis), the proportion of the urban labour force that was out of work increased from $7 \%$ to more than $17 \%$, later falling to around $14 \%$ (between 1997 and 1999) and then shooting up again -with the onset of recession- to above $17 \%$ in 2001 (figure 3).

The growth in unemployment in the 1990s was a generalized phenomenon encompassing the entire country and affecting a variety of population groups with differing characteristics. Young people continued to experience the highest rates, but all age groups were affected similarly by the increase in unemployment. Nevertheless, the rates did rise somewhat more among women than men, paralleling the growth in female participation in the labour force. At the same time, there was an alarming increase in unemployment among heads of household, which jumped from $2 \%-3 \%$ to about $10 \%$ during the last period of expansion (1997) and then grew even worse in the later recession (Altimir and Beccaria, 2000b). The rise in unemployment was also quite generalized among income levels, although

INCOME DISTRIBUTION IN ARGENTINA, 1974-2000 • OSCAR ALTIMIR, LUIS BECCARIA AND MARTIN GONZALEZ ROZADA 
FIGURE 3

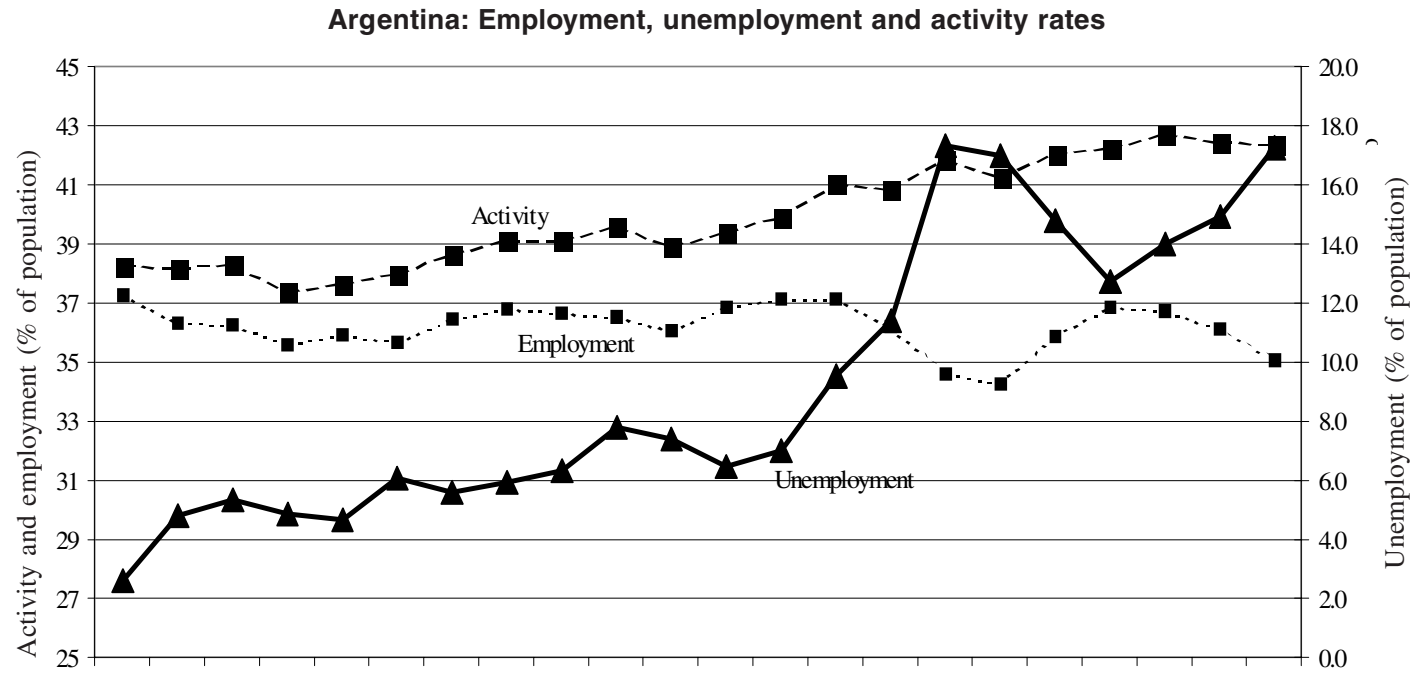

1980198119821983198419851986198719881989199019911992199319941995199619971998199920002001

Years

Source: Developed by the authors on the basis of data from the EPH.

it was somewhat more marked in some of the middle income strata and-in combination with lower activity rates - affected the well-being of the lower-income strata more severely, as will be seen below (table 3 ).

The total employment rate has ranged between $35 \%$ and $37 \%$ of the population since 1980 , with generally cyclical oscillations that grew larger in the $1990 s^{17}$ (figure 3). However, total employment includes both informal employment in activities of low productivity and involuntary time-related underemployment. Damill, Frenkel and Maurizio (2002) analysed the evolution of full-time employment (including voluntary underemployment) and found a clear downward trend that began to steepen in the early 1990 s, falling from a level of 35\%-36\% in the early 1980s to the rate of $32 \%$ registered in 1994 and also in 2000. This means that involuntary underemployment has grown steadily from around $2 \%$ of the urban population to $6 \%$.

The drop in full-time employment has affected males and heads of household, in particular. Moreover, it has been concentrated in the manufacturing sector, where employment rates among women and secondary workers have also decreased, although the participation of these groups in the service sector has increased (Damill, Frenkel and Maurizio, 2002).

${ }^{17}$ During the recession of $1995 / 1996$, the rate fell below $35 \%$.
Between 1974 and 1980, aggregate labour productivity in non-farm activities virtually stagnated. ${ }^{18}$ Ten years later, in the early1990s, non-farm output was lower and urban employment had expanded $10 \%$, with a consequent reduction in labour productivity (table 1). This decline was partially associated with the growth in informal-sector activity, which increased from $38 \%$ to $42 \%$, but the formal sector was also affected by the deterioration in productivity: a survey of medium-sized and large enterprises in the industrial sector revealed a stagnation of productivity between 1980 and 1990 (Altimir and Beccaria, 2000b).

Between 1991 and 1994, non-farm output grew 28\%; however, urban employment scarcely changed (table 1). This signified a rapid increase in the mean productivity of labour, which reflected the absorption of idle capacity associated with the revival of economic activity and partly an increase in output per capita on the production frontier, linked to the restructuring of production. ${ }^{19}$ In contrast, between 1994 and 1997 the

\footnotetext{
${ }^{18}$ After having expanded by more than $3 \%$ a year between 1960 and 1970 , when output grew at a rate of close to $5 \%$ and urban employment increased at a rate of $1.4 \%$ a year.

${ }^{19}$ Frenkel and González Rozada (1998) estimate that half the mean increase in industrial productivity is explained by the cycle effect (increased efficiency in the use of existing resources, owing to the upsurge in economic activity) and the other half by the increase in the capital-output ratio and the use of new technology.
} 
TABLE 3

Unemployment and activity rates by per capita family income group

\begin{tabular}{|c|c|c|c|c|c|c|c|c|c|c|c|c|c|c|c|c|}
\hline \multirow{2}{*}{$\begin{array}{l}\text { Decile of } \\
\text { per capita } \\
\text { family } \\
\text { income }^{\text {a }}\end{array}$} & \multicolumn{2}{|c|}{1974} & \multicolumn{2}{|c|}{1980} & \multicolumn{2}{|c|}{1986} & \multicolumn{2}{|c|}{1989} & \multicolumn{2}{|c|}{1990} & \multicolumn{2}{|c|}{1994} & \multicolumn{2}{|c|}{1997} & \multicolumn{2}{|c|}{2000} \\
\hline & $\begin{array}{l}\text { Acti- } \\
\text { vity } \\
\text { rate }\end{array}$ & $\begin{array}{l}\text { Unem- } \\
\text { ploy- } \\
\text { ment } \\
\text { rate }\end{array}$ & $\begin{array}{l}\text { Acti- } \\
\text { vity } \\
\text { rate }\end{array}$ & $\begin{array}{l}\text { Unem- } \\
\text { ploy- } \\
\text { ment } \\
\text { rate }\end{array}$ & $\begin{array}{l}\text { Acti- } \\
\text { vity } \\
\text { rate }\end{array}$ & $\begin{array}{l}\text { Unem- } \\
\text { ploy- } \\
\text { ment } \\
\text { rate }\end{array}$ & $\begin{array}{l}\text { Acti- } \\
\text { vity } \\
\text { rate }\end{array}$ & $\begin{array}{l}\text { Unem- } \\
\text { ploy- } \\
\text { ment } \\
\text { rate }\end{array}$ & $\begin{array}{l}\text { Acti- } \\
\text { vity } \\
\text { rate }\end{array}$ & $\begin{array}{l}\text { Unem- } \\
\text { ploy- } \\
\text { ment } \\
\text { rate }\end{array}$ & $\begin{array}{l}\text { Acti- } \\
\text { vity } \\
\text { rate }\end{array}$ & $\begin{array}{l}\text { Unem- } \\
\text { ploy- } \\
\text { ment } \\
\text { rate }\end{array}$ & $\begin{array}{l}\text { Acti- } \\
\text { vity } \\
\text { rate }\end{array}$ & $\begin{array}{l}\text { Unem- } \\
\text { ploy- } \\
\text { ment } \\
\text { rate }\end{array}$ & $\begin{array}{l}\text { Acti- } \\
\text { vity } \\
\text { rate }\end{array}$ & $\begin{array}{l}\text { Unem- } \\
\text { ploy- } \\
\text { ment } \\
\text { rate }\end{array}$ \\
\hline \multicolumn{17}{|c|}{ Greater Buenos Aires } \\
\hline 1 & 21.1 & 10.4 & 20.9 & 5.1 & 21.9 & 20.6 & 23.6 & 30.2 & 22.4 & 30.0 & 27.8 & 47.2 & 32.4 & 40.6 & 30.4 & 44.9 \\
\hline 2 & 25.0 & 4.6 & 23.6 & 1.2 & 23.1 & 10.3 & 27.5 & 16.3 & 24.8 & 9.5 & 29.2 & 21.3 & 33.2 & 25.6 & 31.9 & 22.4 \\
\hline 3 & 27.3 & 3.9 & 29.2 & 4.3 & 30.7 & 8.2 & 25.7 & 11.0 & 24.9 & 9.4 & 30.2 & 21.4 & 33.4 & 21.5 & 36.4 & 23.8 \\
\hline 4 & 31.9 & 2.0 & 32.6 & 2.5 & 33.7 & 5.3 & 36.4 & 10.9 & 32.2 & 10.5 & 37.1 & 16.8 & 38.4 & 18.1 & 35.9 & 20.3 \\
\hline 5 & 34.0 & 3.6 & 32.8 & 1.0 & 29.0 & 3.9 & 33.8 & 7.1 & 35.7 & 7.8 & 40.7 & 16.2 & 41.7 & 16.6 & 38.7 & 16.5 \\
\hline 6 & 36.5 & 3.2 & 38.9 & 3.2 & 38.5 & 3.3 & 35.3 & 8.5 & 33.4 & 4.8 & 41.5 & 13.4 & 42.9 & 14.9 & 45.7 & 11.9 \\
\hline 7 & 45.3 & 2.1 & 45.3 & 1.8 & 46.6 & 3.4 & 42.8 & 4.0 & 41.5 & 4.8 & 48.6 & 10.0 & 47.4 & 11.5 & 50.1 & 13.3 \\
\hline 8 & 50.9 & 1.3 & 49.9 & 1.2 & 47.0 & 1.6 & 48.2 & 2.9 & 47.3 & 3.2 & 51.9 & 7.1 & 54.4 & 9.3 & 51.4 & 8.3 \\
\hline 9 & 53.7 & 1.5 & 48.4 & 1.6 & 52.8 & 1.9 & 51.4 & 1.5 & 54.9 & 1.5 & 53.7 & 5.1 & 60.1 & 5.9 & 58.1 & 7.4 \\
\hline 10 & 61.6 & 0.8 & 52.9 & 0.8 & 57.0 & 0.8 & 58.2 & 1.8 & 64.2 & 2.3 & 65.4 & 2.2 & 62.6 & 4.1 & 63.9 & 3.3 \\
\hline Total & 38.7 & 2.7 & 37.5 & 2.0 & 38.0 & 4.6 & 38.3 & 7.5 & 38.2 & 6.6 & 42.6 & 13.4 & 44.6 & 14.7 & 44.2 & 14.9 \\
\hline \multicolumn{17}{|c|}{ Ten interior cities } \\
\hline 1 & & & & & & & & & & & 24.4 & 33.7 & 27.5 & 38.2 & 28.5 & 44.6 \\
\hline 2 & & & & & & & & & & & 30.0 & 19.9 & 29.1 & 26.2 & 30.9 & 27.1 \\
\hline 3 & & & & & & & & & & & 31.7 & 15.1 & 31.5 & 17.5 & 33.2 & 20.6 \\
\hline 4 & & & & & & & & & & & 34.0 & 10.9 & 34.1 & 13.4 & 37.1 & 19.3 \\
\hline 5 & & & & & & & & & & & 37.5 & 10.8 & 38.4 & 15.3 & 37.8 & 16.3 \\
\hline 6 & & & & & & & & & & & 42.2 & 8.4 & 39.1 & 13.5 & 42.1 & 14.2 \\
\hline 7 & & & & & & & & & & & 44.5 & 5.2 & 41.9 & 9.9 & 41.2 & 10.6 \\
\hline 8 & & & & & & & & & & & 45.2 & 4.8 & 45.6 & 7.7 & 45.6 & 9.6 \\
\hline 9 & & & & & & & & & & & 48.8 & 2.9 & 48.3 & 5.8 & 50.1 & 7.5 \\
\hline 10 & & & & & & & & & & & 54.4 & 3.1 & 52.6 & 3.5 & 56.2 & 2.7 \\
\hline Total & & & & & & & & & & & 37.6 & 11.0 & 38.8 & 13.4 & 40.3 & 15.1 \\
\hline
\end{tabular}

Source: Developed by the authors on the basis of data from the EPH.

${ }^{a}$ Excludes households that did not answer, totally or partially, the question on income, but does include households without income.

$11.5 \%$ rise in the level of economic activity was accompanied by $7.2 \%$ growth in urban employment, which then increased another $5 \%$ during the subsequent recession of 1998/2000.

Damill, Frenkel and Maurizio (2002) found that full-time employment in Greater Buenos Aires had shown a significant change in the 1990s, which was reflected in a contraction of the employment rate and which was interpreted as the impact of the new macroeconomic scenario and incentives on demand for full-time employment. They also found that the period of adjustment to the new environment can be considered to have ended by late $1996 .{ }^{20}$ These authors point out,

${ }^{20}$ These authors developed a labour demand model that views the adjustment of demand to a new environment as a gradual process, for which purpose they use two dummy variables: one for the decade of the 1990s and another for observations made after 1996. The coefficient of the first dummy variable (for the entire decade) in addition, that the $2.7 \%$ drop in the full-time employment rate among the urban population between 1992 and 1998 is largely attributable to the reduction in the employment rate in the manufacturing and commerce sectors (-2.1\% and $-1 \%$, respectively) during that period.

During the last quarter of the twentieth century, wages were established under different regimes. In 1976, collective bargaining was suspended and the government set wages. In 1987, labour negotiations resumed. In 1991, reforms were introduced with a view to encouraging decentralized negotiations, at the company level, but with little success (Marshall, 2002).

implies an additional contraction of the full-time employment rate; the coefficient of the second dummy variable (for post-1996 observations) is positive and more or less offsets the contractive effect of the coefficient of the first variable (Damill, Frenkel and Maurizio, 2002, p. 47). 
The real wage level reached a maximum in 1974, marking the culmination of an upward trend that had begun more than a decade earlier (figure 4). It then suffered declines of $14 \%$ in 1975 and $36 \%$ in 1976, the latter as a consequence of the stabilization policy that froze wages, devalued the peso and liberalized prices. After that, wages gradually recovered, finally reaching near 1975 levels five years later in 1980. In a context of large new fluctuations, in 1986 the average wage was more than $7 \%$ lower than it had been in 1980. The hyperinflation and recession of the late 1980s and early 1990s brought the real value of wages down to an absolute minimum: $37 \%$ below the 1980 level. The recovery and later oscillations, in an environment of price stability, have kept the real wage fluctuating at between $20 \%$ and $25 \%$ below that level (table 1 and figure 4 ).
FIGURE 4

\section{Argentina: Evolution of real wages}

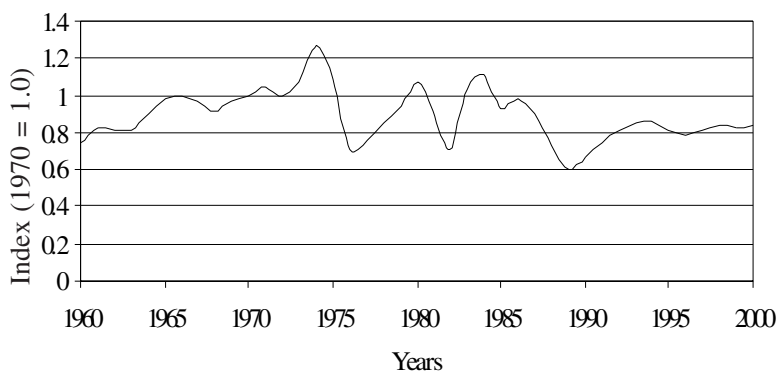

Source: For 1960-1974, see: Llach and Sánchez (1984); for 19742000, see data from EPH (Greater Buenos Aires).

\section{IV}

\section{Impact of labour market changes on family income distribution}

Taking into account the large extent to which household income distribution and its evolution is determined by labour incomes, we chose a quantitative approach that would enable us to examine the influence of various labour market variables on changes in the inequality of household income distribution. The method utilized for that purpose was microsimulation analysis, a tool which makes it possible to quantify the effect of changes in the supply of labour, unemployment and relative wages. The latter are then analysed in greater detail by means of conventional regression analysis.

\section{Microsimulation analysis}

The microsimulation technique consists in simulating, for each individual in the working-age population during a period $t$, the labour situation (activity/passivity, employment/unemployment, occupational category, sector of activity, educational level, wage level) that would have prevailed at time $t+k$ if he/she had experienced the changes in the labour variables that occurred between $t$ and $t+k,{ }^{21}$ taking into account the

\footnotetext{
${ }^{21}$ In the case of Argentina, the analysis of labour market changes must be limited to the labour and income characteristics included in the EPH.
}

socio-demographic characteristics of each individual in period $t$. The incomes of this counterfactual population and the corresponding households are then fed into the model to simulate the distribution of household income in $t+k$.

This technique makes it possible to assess changes in the entire distribution of income -utilizing microsimulated counterfactual populations and assigning to each observation the change that would have occurred in accordance with behaviour functions estimated on the basis of the microdata themselvesand quantify the effect of all the explanatory variables considered (in an alternative or sequential manner). ${ }^{22}$ This procedure contrasts with current methods of decomposing changes in some summary measure of inequality (or poverty) to determine what proportion of those changes reflect changes in the relationships between mean incomes of different population subgroups, variation in the relative importance of each subgroup or changes in the distribution within each subgroup and are therefore attributable to factors other

\footnotetext{
${ }^{22}$ For more detailed information on microsimulation modelling of income distribution dynamics, see Bourguignon, Fournier and Gourgand (1998) and Bourguignon, Ferreira and Lustig (2001).
} 
than the variable used to partition the population for decomposition purposes. ${ }^{23}$

In our case, the procedure consisted in sequentially simulating counterfactual populations - of men and women-that replicated in the population in $t$ the values registered in $t+k$ for the following variables: participation rates; participation and unemployment rates; the two preceding variables and the educational structure of the employed population; and, lastly, this labour force structure with wages calculated by applying the coefficients of the income functions for $t+k$ estimated by regression. In the first three simulations, incomes were assigned either to individuals whose status would have changed because they were included in the simulated population with labour income or to those whose income changed as a result of changes in educational attainment. In each simulation, the family incomes that would have resulted from combining the incomes of the counterfactual population were computed, which made it possible to obtain a simulated distribution of household income and calculate the corresponding measures of concentration and poverty. The analysis of the effect, between $t$ and $t+k$, of each change considered is done by comparing the inequality of the distribution simulated with the change and the inequality of the distribution simulated (earlier in the sequence of simulations) without that change.

As is explained in the methodological appendix, the first step was to estimate-by means of the maximum likelihood method- a polychotomous logit model of labour market participation, for males and females and for each year, that would determine the probability that each person in the working-age population would be inactive, unemployed or employed, as a function of age, marital status, years of formal education, being the head of household or not, having minor children (in the case of women) and attending an educational institution. On that basis and by ranking the individuals according to those probabilities, it was possible to simulate, for each

\footnotetext{
${ }^{23}$ See in Altimir and Beccaria (2000a) an exercise in decomposing changes in the Theil index of the hourly wage distribution of individuals employed full-time for Greater Buenos Aires (1974/ 1997) and for a larger group of urban agglomerations (1991/1997), by five alternative partitions (characteristics) of that population. Also, Altimir and Beccaria (1998) decompose changes in the aggregate incidence of absolute poverty in Greater Buenos Aires (1974/1997), identifying the variations in this measure attributable to changes in the composition of households or heads of households, by different attributes.
}

year $t+k,{ }^{24}$ which individuals in the sample would have become active or inactive (depending on the aggregate change in the male/female participation rate between $t$ and $t+k$ ), unemployed or employed (according to changes in unemployment rates).

The second step was to estimate labour income functions for males and females and for each year, depending on age (as a proxy variable for experience), age squared and five dummy variables corresponding to different levels of formal education. ${ }^{25}$ On that basis, it was possible to impute a wage to individuals who became employed.

By comparing the original distribution for year $t$ with the simulated distribution for the counterfactual population generated using the participation rate for $t+k$, the effect of the change in that variable on family income distribution can be quantified. Similarly, comparing the latter distribution with the simulated distribution for the counterfactual population generated using the participation and unemployment rates for $t+k$ reveals the additional effect of the change in unemployment. ${ }^{26}$

To quantify the effect of change in the educational structure of the population, the counterfactual population generated using the participation and unemployment rates for $t+k$ were ranked, within each sex and activity category, by educational attainment level in $t$. As the probability of having a certain educational level was not modelled, individuals were ranked within each group and level according to a previously assigned random number. This ranking make it possible to select which individuals entered and left each educational level, in accordance with the aggregate change in the educational structure between $t$ and $t+k$. For individuals who changed educational category, wage level was corrected according to the ratio, in year $t$, between mean incomes for the new category and mean incomes for the original category.

\footnotetext{
${ }^{24}$ This exercise was performed for 1980 (for comparison to 1974), 1986, 1990, 1994 and 2000, which were selected for the analytical reasons indicated above.

${ }^{25}$ Primary schooling completed, secondary schooling not completed, secondary schooling completed, university schooling not completed and university schooling completed. The labour income function included the sample selection bias correction term for equation [8] in the appendix, which captures the probability of being employed, given the worker's socio-economic characteristics. ${ }^{26}$ Naturally, when the distribution generated with both rates changed is compared with the distribution registered in $t$, a measure of the combined effect of both changes on income distribution is obtained.
} 
This last counterfactual population were assigned the wages that they would have had in $t+k$ in order to show the additional effect of the wage change on income distribution. This was done using the estimated monthly labour income functions, for every year and sex, and assigning the estimated coefficients for year $t+k$ rather than those for $t$.

The comparison between the counterfactual population with the wages estimated for $t+k$ and the same population with the wages for $t$ shows the effect of the change in wage structure. ${ }^{27}$

\section{Determinants of changes in inequality}

The sequential microsimulation exercise was designed to compare the value of an indicator of the concentration of the household income distribution -in this case, the Gini coefficient of per capita income distribution- at the start of the period with the values corresponding to the distributions that would have resulted from different counterfactual working-age populations - of both males and females, simulated separately- generated by replacing, in a cumulative sequence, activity rate, unemployment, educational structure and wages at the end of the period, but keeping constant the other characteristics of the population at the beginning of the period. The microsimulations performed have a margin of error attributable to the fact that wages for those who are not employed and those who changed educational level were obtained by generating a random disturbance. The simulations were therefore repeated 1000 times, in a Monte Carlo exercise, in order to establish confidence intervals for the estimation of the measures of inequality and poverty.

This exercise made it possible to assess the effect of various changes in the labour market situation on the distribution of family income in Greater Buenos Aires for different subperiods in the last quarter of the twentieth century. ${ }^{28}$

Table 4 summarizes these changes in terms of the indicator of inequality of counterfactual distributions

\footnotetext{
27 As reflected in monthly labour income, which in turn is determined by hourly earnings and number of hours worked, in addition to what might be earned from a possible secondary occupation.

${ }^{28}$ The exercise was limited to Greater Buenos Aires in order to compare the various subperiods identified as relevant over such a lengthy period, since the microdata available for the rest of the country covered only the 1990s.
}

of household income. ${ }^{29}$ The value shown in the row labelled "Change in participation" is the Gini coefficient of the distribution that would have existed if the activity rate had been what it was in the final year, rather than the initial year, of the subperiod. The following rows show the Gini coefficient of the household distribution that would have existed if the participation and unemployment rates registered at the end of the subperiod had prevailed at the beginning, and so on, successively incorporating changes in educational structure and earnings.

Table 5 shows the effects of each of those changes, in the sequence in which they were simulated, in terms of point changes in the Gini coefficient from one successive counterfactual population to the next, for each of the subperiods. The difference between the Gini coefficient for the distribution that incorporates all the changes considered and the actual coefficient at the end of the subperiod is the part of the variations in effective concentration of per capita income that is not explained by this labour market model; it is therefore attributable to the effect of changes in other factors, some also labour-related -such as the sector of activity or occupational category- and others unrelated to labour -such as non-labour income or household size and composition. Judging from the values in table 5, these factors had a significant influence -similar to that of the set of factors considered in the simulation modelon the increase in inequality. ${ }^{30}$

\footnotetext{
${ }^{29}$ The 95\% confidence intervals for the estimation of each coefficient are included. These intervals, calculated by means of a Monte Carlo procedure that involved 1000 simulations for each one, make it possible to determine whether the effect of each variable (represented by the difference between the mean Gini coefficient estimated by changing the values of the variable at the end of the period and the coefficient estimated with the values at the beginning of the period) on inequality is statistically significant. This is established by testing the hypothesis that the difference between the two Gini coefficients is null or, in other words, that the Gini coefficient estimated without modifying the variable falls within the confidence interval for the estimation of the Gini coefficient with the variable modified, in which case the difference (the effect of that variable) is not statistically significant.

${ }^{30}$ However, the other labour-related factors appear to have been of secondary importance. In a similar microsimulation exercise for the period 1991-1998, Frenkel and González Rozada (2000) also considered the effect of changes in the structure of employment by sector of activity. Those changes, which were simulated by those authors after considering changes in participation and unemployment rates but before looking at modifications in the educational structure, appear to have had a relatively minor effect in terms of lessening inequality.
} 
TABLE 4

Argentina: Estimates of inequality of per capita household income in successive counterfactual populations, various periods ${ }^{a, b}$

(Gini coefficients)

\begin{tabular}{lccccc}
\hline Period & $1974-1980$ & $1980-1986$ & $1986-1990$ & $1990-1994$ & $1994-2000$ \\
\hline Coefficient observed at start of period & 0.367 & 0.394 & 0.419 & 0.459 & 0.482 \\
Change in participation & 0.360 & 0.400 & 0.411 & 0.455 & 0.468 \\
& $(0.359,0.360)$ & $(0.399,0.403)$ & $(0.409,0.413)$ & $(0.453,0.458)$ & $(0.465,0.471)$ \\
Change in participation and unemployment & 0.360 & 0.438 & 0.416 & 0.469 & 0.469 \\
& $(0.359,0.361)$ & $(0.437,0.440)$ & $(0.412,0.418)$ & $(0.467,0.473)$ & $(0.466,0.472)$ \\
$\begin{array}{l}\text { Change in participation, unemployment } \\
\text { and educational structure }\end{array}$ & 0.360 & 0.403 & 0.415 & 0.457 & 0.463 \\
& $(0.359,0.362)$ & $(0.401,0.407)$ & $(0.413,0.418)$ & $(0.452,0.463)$ & $(0.459,0.467)$ \\
$\begin{array}{l}\text { Change in participation, unemployment } \\
\text { educational structure and earnings }\end{array}$ & 0.378 & 0.395 & 0.434 & 0.470 & 0.493 \\
& $(0.377,0.378)$ & $(0.394,0.396)$ & $(0.432,0.435)$ & $(0.465,0.474)$ & $(0.490,0.496)$ \\
Coefficient observed at end of period & 0.394 & 0.419 & 0.459 & 0.482 & 0.510 \\
\hline
\end{tabular}

Source: Developed by the authors on the basis of data from the EPH.

a The figures in italics are estimates whose difference from the preceding estimate in the sequence is not statistically significant at $95 \%$ confidence level.

b The figures between parentheses are 95\% confidence intervals for the Gini coefficient estimates for the simulated distributions.

TABLE 5

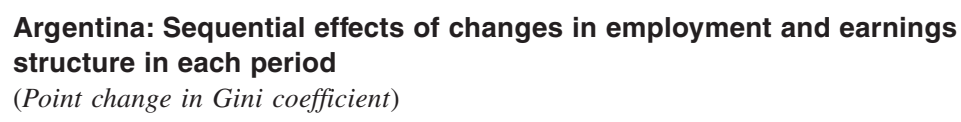

\begin{tabular}{lccccc}
\hline Period & $1974-1980$ & $1980-1986$ & $1986-1990$ & $1990-1994$ & $1994-2000$ \\
\hline Gini coefficient at start of period & 0.367 & 0.394 & 0.419 & 0.459 & 0.482 \\
Effect of participation & -0.007 & 0.006 & -0.008 & -0.004 & -0.014 \\
Effect of unemployment & $\ldots{ }^{\mathrm{a}}$ & 0.038 & 0.005 & 0.014 & $\ldots$ \\
Effect of educational structure & $\ldots$ & -0.035 & $\ldots$ & -0.012 & -0.006 \\
Effect of earnings & 0.018 & -0.008 & 0.019 & 0.013 & 0.030 \\
Unexplained change & 0.016 & 0.024 & 0.025 & 0.012 & 0.017 \\
Gini coefficient at end of period & 0.394 & 0.419 & 0.459 & 0.482 & 0.510 \\
Change in inequality & 0.027 & 0.025 & 0.040 & 0.023 & 0.028 \\
\hline
\end{tabular}

Source: Developed by the authors on the basis of data from the EPH.

a (...) indicates that the change was not significant at $95 \%$ confidence level.

The change in participation rates almost always had a favourable effect in terms of reducing inequality, although it was of secondary importance. The increase in unemployment, on the other hand, had a pernicious effect, especially in the subperiods 1980-1986 and 1990-1994. The change in educational structure had a consistent equalizing effect, although of variable importance. The change in earnings contributed substantially in almost all subperiods to an increase in inequality (figure 5).

For the 1970s, as from 1974, more than half of that increase can be attributed to the change in relative earnings (table 5), whose effect was only partially offset by that of the change in activity rates, which went down

INCOME DISTRIBUTION IN ARGENTINA, 1974-2000 • OSCAR ALTIMIR, LUIS BECCARIA AND MARTIN GONZALEZ ROZADA 
FIGURE 5

Argentina: Sequential effects, by period, of changes in employment and earnings structure on household income distribution

(Point changes in Gini coefficients)

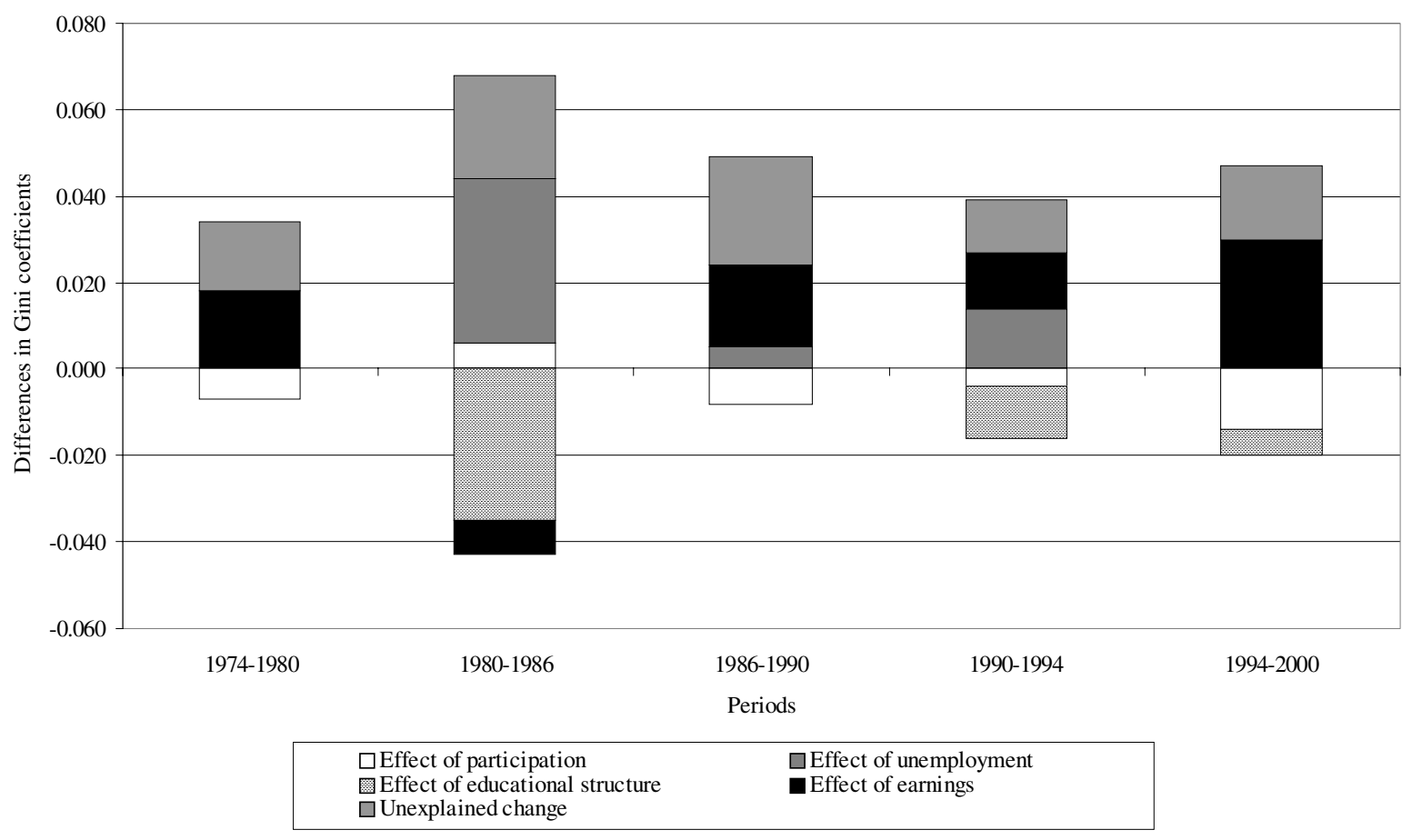

Source: Developed by the authors on the basis of data from the EPH (Greater Buenos Aires).

significantly among households in the upper deciles of the distribution. An increase in inequality of similar magnitude between 1980 and 1986, on the other hand, is not well explained by the labour market changes considered in the model. The effect of the notable increase in unemployment in the first deciles of the income distribution during this period (table 3) was offset by the equalizing impact of the changes in the educational structure. ${ }^{31}$ Similarly, the slight unequalizing influence of the changes in participation rates was offset by a counter-trend in earnings. Between 1986 and 1990, inequality in per capita family income distribution increased almost as much as in the two preceding periods. Around half of that increase is

\footnotetext{
${ }^{31}$ During this period, the proportion of the unemployed population with no schooling or incomplete primary schooling decreased from $16 \%$ to $11.6 \%$, while the proportion of the employed population that had completed secondary school or had received some (but had not completed) post-secondary schooling increased from $22 \%$ to $26.4 \%$.
}

explained by the greater dispersion of relative earnings by education level, whereas the equalizing effect of the changes in activity rates was almost totally neutralized by the negative influence of increased unemployment.

Between 1990 and 1994, the inequality of family incomes again worsened significantly. Only half of this deterioration was due to labour market changes resulting from: (i) the spectacular increase in unemployment in the lowest income strata (table 3), (ii) the amplification of earnings differences by education level and (iii) the continual change in the educational structure of workers, which exercised a countervailing influence. The increase in activity rates, which reached unprecedented levels in 1994, was quite generalized and therefore had little effect on income inequality.

The subsequent rise in inequality between 1994 and 2000 , also, is only partly explained by labour market changes, namely: (i) a substantial widening -larger than in any previous subperiod- of the income gap between workers with different educational levels, 
Argentina: Evolution of employment by education level

$(1991=100)$

\begin{tabular}{|c|c|c|c|c|c|c|c|}
\hline & 1974 & 1980 & 1986 & 1991 & 1994 & 1997 & 2000 \\
\hline Total for all urban agglomerations & $\ldots \ldots$ & $\ldots \ldots$ & $\ldots \ldots$ & 100.0 & 101.3 & 108.6 & 114.1 \\
\hline Primary level not completed & $\ldots \ldots$ & $\ldots \ldots$ & $\ldots \ldots$ & 100.0 & 81.9 & 82.6 & 66.1 \\
\hline Primary level completed & $\ldots \ldots$ & $\ldots \ldots$ & $\ldots \ldots$ & 100.0 & 98.0 & 96.2 & 94.0 \\
\hline Secondary level not completed & $\ldots \ldots$ & $\ldots \ldots$ & $\ldots \ldots$ & 100.0 & 102.4 & 111.6 & 113.2 \\
\hline Secondary level completed & $\ldots \ldots$ & $\ldots \ldots$ & $\ldots \ldots$ & 100.0 & 105.3 & 110.1 & 127.3 \\
\hline Higher/university level not completed & $\ldots \ldots$ & $\ldots \ldots$ & $\ldots \ldots$ & 100.0 & 106.0 & 135.7 & 153.2 \\
\hline Higher/university level completed & $\ldots \ldots$ & $\ldots \ldots$ & $\ldots \ldots$ & 100.0 & 117.9 & 136.5 & 162.0 \\
\hline Greater Buenos Aires & 82.5 & 87.6 & 93.5 & 100.0 & 100.3 & 107.1 & 110.3 \\
\hline Primary level not completed & 193.0 & 146.5 & 126.6 & 100.0 & 76.0 & 80.6 & 65.3 \\
\hline Primary level completed & 89.7 & 98.3 & 94.6 & 100.0 & 97.6 & 92.5 & 88.0 \\
\hline Secondary level not completed & 70.5 & 80.3 & 94.7 & 100.0 & 99.8 & 108.6 & 112.3 \\
\hline Secondary level completed & 52.4 & 66.6 & 80.1 & 100.0 & 107.1 & 108.3 & 122.9 \\
\hline Higher/university level not completed & 57.7 & 71.9 & 84.3 & 100.0 & 106.9 & 142.4 & 145.7 \\
\hline Higher/university level completed & 37.8 & 56.3 & 83.1 & 100.0 & 117.6 & 141.8 & 166.8 \\
\hline Interior cities & $\ldots \ldots$ & $\ldots \ldots$ & $\ldots \ldots$ & 100.0 & 102.8 & 110.9 & 119.5 \\
\hline Primary level not completed & $\ldots \ldots$ & $\ldots \ldots$ & $\ldots \ldots$ & 100.0 & 89.4 & 85.0 & 67.2 \\
\hline Primary level completed & $\ldots \ldots$ & $\ldots \ldots$ & $\ldots \ldots$ & 100.0 & 98.6 & 102.7 & 104.1 \\
\hline Secondary level not completed & $\ldots \ldots$ & $\ldots \ldots$ & $\ldots \ldots$ & 100.0 & 106.1 & 116.0 & 114.5 \\
\hline Secondary level completed & $\ldots \ldots$ & $\ldots \ldots$ & $\ldots \ldots$ & 100.0 & 102.5 & 112.9 & 134.1 \\
\hline Higher/university level not completed & $\ldots \ldots$ & $\ldots \ldots$ & $\ldots \ldots$ & 100.0 & 104.9 & 127.1 & 162.0 \\
\hline Higher/university level completed & $\ldots \ldots$ & $\ldots \ldots$ & $\ldots \ldots$ & 100.0 & 118.3 & 129.9 & 156.1 \\
\hline
\end{tabular}

Source: Developed by the authors on the basis of data from the EPH.

a trend that was offset only partially by (ii) the effect of another increase in activity rates, which was comparatively more intense among low-income households, and (iii) the acknowledged equalizing effect of changes in the educational structure of the working population, among whom the proportion with secondary and higher education continued to grow (table 6).

\section{Unit earnings and hours worked}

The income used in the simulations described above is the monthly labour income of employed individuals. Its effects on the distribution of family income reflect a combination of the effect of changes in the inequality of unit earnings and the effect of changes in the differences in hours worked. Those changes have exercised a significant effect only in some periods, sometimes lessening and sometimes worsening the inequality of unit wages. Between 1974 and 1980, the considerable increase in the inequality of hourly earnings was mitigated by improvement in the distribution of hours worked. The opposite occurred between 1980 and 1986, when the decrease in the inequality of hourly earnings changed into a moderate increase in the inequality of monthly incomes (figure 6). However, between 1990 and 1991, the significant reduction in the inequality of hourly earnings resulted in only a slight reduction of the inequality in monthly incomes, owing to an increase in the disparity in hours worked by members of different income strata. During the period 1996-2000, on the other hand, the changes in this differential intensity of work attenuated the increase in inequality of hourly incomes. Hence, changes in the differences in hourly incomes have, in essence, determined the trend in distribution of personal income among employed workers (figure 6).

However, the distribution of hourly incomes encompasses occupations of all types and of differing duration and therefore includes situations of both voluntary and involuntary underemployment which, as noted above, increased during the 1990s. For that reason, we also analysed the evolution of hourly income distribution among employed individuals with a single 
FIGURE 6

Argentina: Distribution of monthly and hourly income among employed workers in Greater Buenos Aires, 1974-2000

(Gini coefficients)

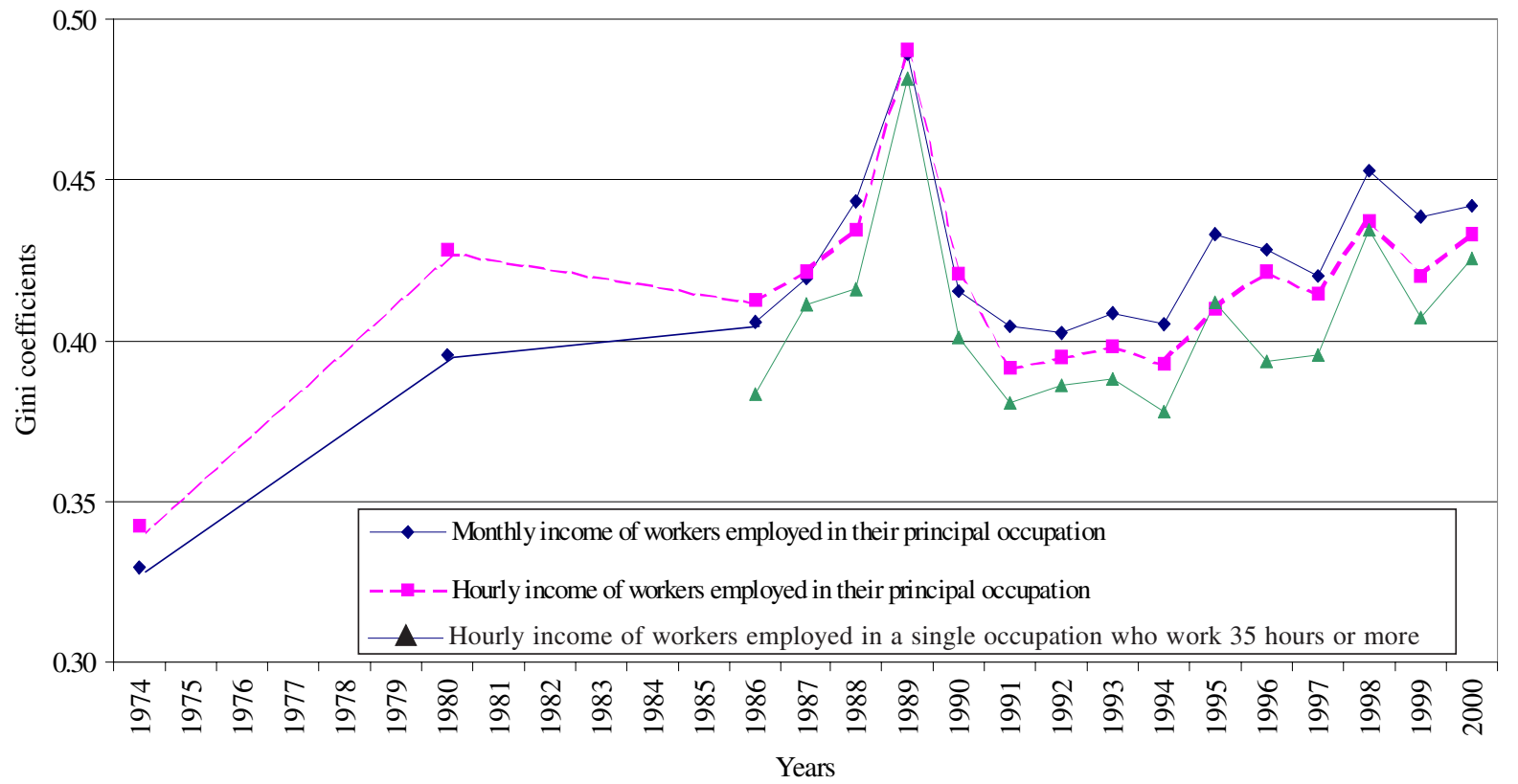

Source: Developed by the authors on the basis of data from the EPH.

occupation who worked at least 35 hours a week, as that is the survey concept that most closely approximates unit earnings for full-time jobs. Although it shows a greater natural variability, the trend exhibited by the concentration of that distribution, between the years selected as those of greatest relative macroeconomic normality (figure 6), is even clearer than that exhibited by the concentration of the distribution of all hourly earnings: Gini coefficient of 0.38 in 1986, 1991 and 1994, which rose to almost 0.40 in 1997, although it later jumped to 0.44 in the first phase of the current recession.

\section{Determinants of changes in relative earnings}

Underlying this evolution of the inequality of hourly earnings there may be changes -sometimes counteracting changes- in the earning differentials associated with differing characteristics of employed individuals that might reveal the influence exerted, from period to period, by variables of labour supply and demand. To find evidence to support this idea, Mincertype income functions were estimated, in which the logarithm of hourly earnings for full-time principal occupations (for the sample for each year selected) is related to the characteristics of employed persons with a single occupation: education level, sector of activity, ${ }^{32}$ occupational category, age, sex and head-of-household status (table 7). The coefficients estimated for each category of a characteristic -controlling for the othersrepresent the "earning differential" or "reward" for that category with respect to the category taken as a reference.

The evolution of earning differentials by educational level provides more information on the trends at work in each period behind the unequalizing effect of the changes in the structure of remuneration of human capital on household income distribution. This effect was quantified in the simulation exercise and is shown in figure 5. The rewards to the highest educational levels (completed secondary schooling, tertiary education) increased throughout the last quarter of the twentieth century. Almost all those increases occurred between 1974 and 1980. By the end of the crisis decade of the 1980s, despite a sharp decline (39\% on average) in real hourly earnings, the differences between levels were similar to those that had existed in

${ }^{32}$ Disaggregated into five sectors in accordance with the size of the sample.

INCOME DISTRIBUTION IN ARGENTINA, 1974-2000 • OSCAR ALTIMIR, LUIS BECCARIA AND MARTIN GONZALEZ ROZADA 
TABLE 7

Greater Buenos Aires: Income functions, selected years ${ }^{a, b}$

(Dependent variable, logarithm of hourly wage in principal occupation)

\begin{tabular}{|c|c|c|c|c|c|c|c|}
\hline & 1974 & 1980 & 1986 & 1990 & 1994 & 1997 & 2000 \\
\hline \multicolumn{8}{|l|}{ Education } \\
\hline \multicolumn{8}{|l|}{ Primary level } \\
\hline \multicolumn{8}{|l|}{ Secondary level } \\
\hline Secondary level completed & 0.3589101 & 0.5126224 & 0.4044073 & 0.4949932 & 0.4127261 & 0.4530148 & 0.4450138 \\
\hline Tertiary level not completed & 0.4276585 & 0.657878 & 0.646664 & 0.7833223 & 0.669927 & 0.6419327 & 0.6814434 \\
\hline Tertiary level completed & 0.8239498 & 1.042674 & 0.9171951 & 0.9802195 & 0.9826189 & 1.08574 & 1.149472 \\
\hline \multicolumn{8}{|l|}{ Individual characteristics } \\
\hline Sex & 0.3736265 & 0.343417 & 0.2720114 & 0.201527 & 0.1710177 & 0.1896878 & 0.2040489 \\
\hline Age & 0.0418729 & 0.0469294 & 0.0552483 & 0.0494946 & 0.0478113 & 0.0450942 & 0.0438228 \\
\hline $\mathrm{Age}^{2}$ & -0.0004466 & -0.0004912 & -0.0005819 & -0.0004927 & -0.0004959 & -0.0004092 & -0.0003891 \\
\hline \multicolumn{8}{|l|}{ Sectors of activity } \\
\hline Construction & $-0.0493249^{c}$ & $-0.029007^{\mathrm{c}}$ & -0.1515462 & $-0.1601648^{\mathrm{d}}$ & $0.0064477^{\mathrm{c}}$ & $0.0028718^{c}$ & $-0.012539^{c}$ \\
\hline Commerce & -0.1575408 & $-0.0511649^{\mathrm{e}}$ & -0.1715423 & -0.1603177 & -0.1629117 & -0.259589 & -0.2428781 \\
\hline Transport and finance & $-0.022376^{\mathrm{c}}$ & $0.0679954^{\mathrm{e}}$ & $0.047942^{\mathrm{c}}$ & $0.0532897^{\mathrm{c}}$ & $-0.0119688^{c}$ & $-0.0496745^{\mathrm{c}}$ & -0.1161936 \\
\hline Public administration & $0.1287654^{\mathrm{d}}$ & $0.0014316^{\mathrm{c}}$ & $-0.0855258^{c}$ & -0.2636433 & $0.0670934^{\mathrm{c}}$ & $-0.0076822^{\mathrm{c}}$ & $0.070859^{\mathrm{c}}$ \\
\hline Other services & -0.1911927 & $-0.0769389^{d}$ & -0.126884 & -0.1847071 & $-0.0366766^{\mathrm{c}}$ & -0.121029 & -0.0938155 \\
\hline \multicolumn{8}{|l|}{ Occupational category } \\
\hline Unregistered wage-earners ${ }^{\mathrm{f}}$ & -0.2526092 & -0.1478836 & -0.1049085 & -0.2737152 & -0.1390019 & -0.2548484 & -0.2722385 \\
\hline Non-wage-earners & -0.0689237 & 0.1508761 & 0.1042153 & $-0.0804171^{\mathrm{d}}$ & $0.0252879^{\mathrm{c}}$ & -0.0822184 & -0.1526577 \\
\hline Constant & 1.172632 & 7.18064 & -1.225262 & 6.94072 & -0.2307537 & -0.2137342 & -0.2440764 \\
\hline Adjusted $\mathrm{R}^{2}$ & 0.3555 & 0.3345 & 0.3508 & 0.2956 & 0.3038 & 0.3956 & 0.4057 \\
\hline Number of observations & 3423 & 2836 & 3271 & 1914 & 2534 & 2642 & 2597 \\
\hline
\end{tabular}

Source: Developed by the authors on the basis of data from the EPH.

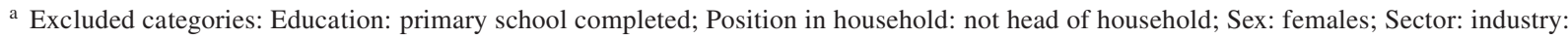
Occupational category: registered ${ }^{f}$ wage-earners.

${ }^{\mathrm{b}}$ Regression coefficients significant at $1 \%$, unless otherwise indicated.

c Not significant at $10 \%$.

${ }^{d}$ Significant at $5 \%$.

e Significant at $10 \%$.

f I.e., not registered with the social security system.

$1980 .{ }^{33}$ In 1994, at the culmination of the period of recovery and growth, the rewards for intermediate levels of qualification (completed secondary and incomplete tertiary education) had diminished. By around 1997, the returns to completed tertiary education had exceeded those reached in 1980, while those corresponding to other education levels remained close to the 1980 levels. This differentiation became even more pronounced during the later recession, when the returns to completed primary education and incomplete secondary education decreased, but those for completed tertiary education continued to grow (table 7).

\footnotetext{
${ }^{33}$ The only noteworthy change is the increase in the rewards to incomplete tertiary education and the reduction in rewards to completed tertiary education (table 7).
}

In the urban agglomerations of the interior, the returns to higher education are of lesser magnitude than in Greater Buenos Aires. Throughout the 1990s, this has meant smaller relative differences in wages, which helps to explain the lower levels of inequality in income distribution among employed workers in those cities (figure 1).

The relative importance of the change not explained by the factors considered in the simulation exercise has already been noted (figure 5). Part of that effect may be due to changes in the relative earnings for the various occupational categories. The equations from table 7 show, between 1974 and 1980, a significant widening of the gap between the incomes of non-wageearners (mainly self-employed workers) and those of wage-earners registered in the social security system. 
The gap narrowed in the 1980s and finally, during the 1990s, turned to a larger negative differential than had existed in 1974. As for wage-earners not registered with the social security system, their (negative) income differential improved in the 1980s and then again in 1994, and by 1997 had returned to its 1974 level.

The changes in differential incomes for the various sectors of activity, also, were not explained by the simulation exercise. However, their impact in the evolution of inequality appears to have been more diffuse. Among the significant changes, the following are worth noting: the deepening of the wage differential for public administration (vis-à-vis industry) between 1974 and 1986, which then lessened somewhat in the 1990s; the deterioration, beginning in 1997, of the differential for commerce; and the improvement of the differential for other services, both in 1980 and again in 1994 (table 7).

With regard to the gender earnings differential, the income advantage of males declined, particularly in the 1980s, and then the trend levelled off in the 1990s. In contrast, the age advantage -among employed individuals- remained stable throughout the period studied.

\section{Influence of other resources on household income distribution}

The trend of household income distribution has been determined mainly by the evolution of the inequality of labour incomes and opportunities for obtaining them by offering time and human capital on the labour market. However, household members possess other assets -fixed and financial- that generate income, as well as entitlements to cash transfers from social welfare systems (pensions, etc.). ${ }^{34}$ Changes in the distribution of this non-labour income can influence, in the short term, the evolution of the concentration of household income and can even modify the trend of labour income.

These effects can be appreciated indirectly by examining the evolution of the inequality of the various types of income (see table 8) between the top and bottom quintiles of the household income distribution. With regard to retirement pensions, although between 1980 and 1986 the disparities between strata lessened, both in the proportion of pensioners and the mean value of pensions, they grew larger thereafter. In general, pensions have a regressive influence on the aggregate distribution; consequently, the growing disparity

\footnotetext{
34 The EPH does not provide sufficient information to obtain estimates of the value of the transfers received in the form of free or highly subsidized public services (education, health, food, etc.), nor does it include questions on gross income prior to deductions or payment of contributions. For these two reasons, the household income distribution analysed here relates mainly to the total "takehome pay" of household members.
}

between strata had some impact -though moderate in comparison with that of the labour variables- on the increase in inequality among households in the 1990s. ${ }^{35}$

The evolution of property income also contributed to a widening of the disparity in household income in the 1990s. According to data from the $\mathrm{EPH},{ }^{36}$ between 1994 and 1997 the mean value of this type of income increased considerably for the upper strata of the

\footnotetext{
${ }^{35}$ In a previous work (Altimir and Beccaria, 2000a), the authors used a model of per capita income formation to decompose different measures of inequality (ratio between mean values for the top and bottom income quintiles and Gini coefficient), in terms of labour and non-labour variables - like those in table 8- and performed alternative simulations, for each year, of what the inequality of the aggregate distribution would have been if the inequality of each variable considered in the model had not existed, thus assessing the effect of the variable on overall inequality. The analysis of the effect of non-labour income in this section is based on the results of that study.

${ }^{36}$ The EPH is presumed to underestimate cash property income, owing both to the difficulty of including the few recipients of this type of income in the sample and to underreporting and other response biases that affect the capture of data on non-labour income. Moreover, a significant portion of profits and other property income generated in the productive process are retained, institutionally and from an accounting standpoint, by businesses. This income is thus incorporated directly into the business owners' equity and is never reflected in the flow of income that they receive as members of households. For those two reasons, analysis of the effect of property income on aggregated income distribution based on data from the EPH is limited and biased.
} 
Argentina: Inequality of certain characteristics between the top and bottom quintiles of the per capita household income distribution

(Mean value for the fifth quintile/mean value for the first quintile)

\begin{tabular}{lccccccc}
\hline & 1974 & 1980 & 1986 & 1990 & 1994 & 1997 & 2000 \\
\hline Per capita household income & 6.77 & 8.04 & 8.91 & 11.71 & 12.6 & 15.04 & 17.09 \\
& & & & & & & \\
& 1.34 & 1.24 & 1.09 & 1.14 & 1.50 & 2.05 & 3.08 \\
Proportion of pensioners & 2.12 & 2.80 & 2.15 & 2.52 & 3.87 & 4.54 & 3.83 \\
Mean value of pensions & 1.82 & 2.78 & 2.66 & 1.83 & 1.30 & 1.11 & 0.78 \\
Proportion of recipients of other income & 5.18 & 4.59 & 5.13 & 3.60 & 4.76 & 7.53 & 8.4 \\
Mean value of other income per recipient & & & & & & \\
& 1.5 & 1.46 & 1.45 & 1.54 & 1.48 & 1.49 & 1.46 \\
Proportion of individuals over age 15 & 1.74 & 1.52 & 1.60 & 1.72 & 1.43 & 1.29 & 1.28 \\
Activity rate among over-15 individuals & 1.03 & 1.05 & 1.14 & 1.22 & 1.45 & 1.57 & 1.58 \\
Proportion of active population employed & 1.80 & 1.60 & 1.82 & 2.09 & 2.07 & 1.57 & 2.02 \\
Employment rate & & & & & & & \\
\hline
\end{tabular}

Source: Developed by the authors on the basis of data from the EPH.

distribution, in comparison with the lower strata (table 8). However, this situation, which was associated to a large extent with the growth in time deposits, may be somewhat deceptive in a context of price stability if the survey included property income that had not previously been captured or which had been expressed in terms of capital gains resulting from an increase in the value of assets. ${ }^{37}$

Another significant contributor to inequality-in orders of magnitude comparable to the differences in activity rates-is the differences in the demographic structure of households in different strata, which generally work in favour of the wealthy (Altimir and Beccaria, 2000a). However, the variations in this inequality, which have remained relatively stable around an almost stationary trend, have had little influence on the evolution of inequality among households. Perhaps the most noteworthy effects have been those exercised by the narrowing of the disparities between 1974 and 1980, which helped mitigate the growth in the inequality of per capita household income distribution, and the temporary increase in the differences in demographic dependency in 1988/1991, which had the opposite effect (table 8).

\section{VI}

\section{Deterioration of the distribution of family income}

Unquestionably, as can be seen in figure 1, the evolution of household income distribution has been strongly influenced by the distribution of labour income. However, on two occasions, the trend of inequality among households diverged from that of inequality among individual income-earners: in the first case, this divergence later reversed; in the second, it became more pronounced, which meant that the trend of inequality rose more sharply among households than among individuals. Between 1974 and 1980, the considerable

\footnotetext{
${ }^{37}$ Such as dollar holdings, for example.
}

increase in the disparities between earnings and between income-earners had hardly any impact on household income distribution, owing to the equalizing of participation rates among strata. The divergence narrowed between 1980 and 1986, partly as a result of growing disparities in participation rates, but mainly due to the rise in unemployment, which affected the lower strata almost exclusively (table 3). In 1989, at the height of the hyperinflationary period, household inequality jumped 0.037 Gini coefficient points above inequality among individual earners (whereas the previous year the two figures had been about the same).

INCOME DISTRIBUTION IN ARGENTINA, 1974-2000 • OSCAR ALTIMIR, LUIS BECCARIA AND MARTIN GONZALEZ ROZADA 
This difference held steady until 1994, when it expanded again.

In 1989, unemployment increased, but once again the increase was concentrated in the lower income strata, in which the rate rose to over $20 \%$, climbing more than six percentage points. The incipient economic revival of 1990, which marginally lowered aggregate unemployment, did not significantly reduce the high rates of unemployment in the lower strata, and at the same time the disparity in activity rates between strata grew (table 3). ${ }^{38}$ Around 1994, households in the lower half of the income distribution exhibited very high unemployment rates, which exacerbated the inequality of the distribution, distancing it even further from that of individual wage-earners and sharpening its upward trend. As was observed in the microsimulation exercise, during the period 1990-1994, the unequalizing impact of unemployment was counterbalanced only to a small extent by the equalizing effect of participation, which increased significantly in all income strata, with little differential effect. In fact, the behaviour of labour supply in this period, in the face of existing demand, points to an association between the increase in the participation rate $^{39}$ (from $38.2 \%$ to $42.6 \%$ in the aggregate) and the unemployment rate (from $6.6 \%$ to $13.4 \%$ of the active population): the increment in the latter amounted to more than half the enlargement of the active population, but in households earning less than the median income the ratio was even greater. This suggests that, in most cases, the attempt to move from inactivity to employment was unsuccessful and, based on the results of the microsimulation (figure 5), probably contributed significantly to the increase in inequality among households as we measured it. ${ }^{40}$ Between 1994 and 1997

\footnotetext{
${ }^{38}$ This evolution is not apparent in the decomposition undertaken through the simulation exercise, in which the negative effect (i.e., reduction of inequality) of the change in participation rates between 1986 and 1990 (table 5) reflects the effect of the favourable changes that occurred between 1986 and 1988, the virtual neutrality of those that occurred in 1989 and the unequalizing effect of those in 1990. The positive effect (i.e., increase in inequality) of the changes in unemployment during that same period occurred between 1986 and 1988 and, especially, in 1989.

${ }^{39}$ This increase was more marked among women and young people (Altimir and Beccaria, 2000b).

${ }^{40}$ From another perspective, the fact that formerly inactive, nonincome-earning members of a household become active but remain unemployed and still do not earn an income causes no change in the actual flow of income to the household. Nevertheless, the household's well-being can be considered to have changed, since the household member's desire to work (for whatever reason) and to exercise his/her freedom to choose how to apply the assets he/ she possesses is thwarted by the lack of opportunities to do so.
}

the activity rate continued to rise (reaching $44.2 \%$ of the population), as did unemployment, ${ }^{41}$ which affected $14.7 \%$ of the now expanded labour force. Once again, the increase in unemployment amounted to more than half the growth in the active population, but this phenomenon occurred unevenly across the income pyramid, and it therefore had little distributive effect (table 3). In 2000, in the midst of the recession, aggregate rates of participation and unemployment did not differ greatly from those registered in 1997. However, during this period some changes did occur in participation rates among the rich and the poor, the net result being the equalizing effect detected in the microsimulation exercise.

These events led to a steady rise - between the years with the least cyclical component- in the inequality of household income, while, at the same time, income inequality among employed individuals remained relatively unchanged between 1986, 1990/1991 and $1992 / 1994$. The unequalizing effect of the increase in unemployment at the end of the 1980s never reversed and is, therefore, at the root of the deterioration of the distribution of family income. ${ }^{42}$ The situation was compounded by the effect of a new wave of unemployment, whose structural nature became clearly apparent in 1994, when the economy reached a high utilization of its recently expanded productive capacity. Between 1994 and 1997, however, the increase in the inequality of household incomes was more closely linked to the exacerbation of inequality within the productive apparatus (figure 1), an influence that continued to make itself felt in the later increase during the recessionary phase, up until the year 2000.

In comparison with labour income (earnings, participation and unemployment), the evolution of nonlabour incomes has only marginally affected the increase in inequality of household income. As has already been noted, the evolution of both pensions and property income contributed in the 1990s to an increase in inequality, but only to a small extent in relation to the overall increase ${ }^{43}$ (table 8).

\footnotetext{
${ }^{41}$ Even without considering the significant rise in unemployment posted during the recession of 1995/1996 (figure 3).

${ }^{42}$ There may also be other factors not considered in the microsimulation exercise -which would therefore be operating inside the "black box" comprising the unexplained portion of the change in inequality- which may have acted with a certain hysteresis or may have undergone permanent changes that have fostered inequality among households but not among individual income earners.

${ }^{43}$ If only the property income captured by the EPH is considered. Such income constitutes a minor proportion of total household income which could be estimated if information were available on
} 


\section{VII}

\section{The role of economic policy and reforms}

Economic policies have a decisive impact on income distribution. The success or failure of macroeconomic regulation influences the level of activity and employment. The macroeconomic regime, sectoral regimes and regulation of markets give rise to the system of incentives that drive investment, which, in turn, influences the demand for labour and wages. Fiscal policy, too, has numerous distributive repercussions. However, it would be a mistake to attribute all responsibility for the evolution of income distribution to economic policy. In mixed economies, income distribution is also shaped by the autonomous decisions of businesses and by the behaviour of households, given the distribution of wealth, in an environment created by the incentives arising from markets -both internal and external-, institutions that regulate the economic order, the macroeconomic regime and provisions that regulate markets, in a scenario in which the State is also a major economic actor.

This discussion of the "environmental" role of economic policy is intended to strip it of the image of omnipotence with which it is often analysed, both in terms of its origins and its consequences, with the corollary that economic policy is seen as accounting for everything that happens in the economy. It is also intended to point up the strong influence of patterns of structural change -including those that shape the political system and the government apparatus- which act largely outside the economic policy sphere. All that said, it cannot be denied that public policy does have tremendous power to influence and foster the achievement of results -or to generate shocksespecially in fledgling economies with incipient institutions and many incomplete markets.

Given the difficulties of effectively modelling the complex relationships between economic policy and the distribution of wealth and income, we attempted to assess the influence of the former on the latter by looking at the temporal association of major changes in economic policy (institutional reforms, macroeconomic regime and labour regulation) and the ensuing changes in the system of incentives with the apparent behaviour of the demand for labour revealed by the changes in the labour market which, according to our microsimulation analysis, have had the greatest distributive impact.

\section{The reform attempt of the 1970 s}

The three year period between 1973 and 1975 was dominated by the ultimately unsuccessful attempt of the Perón government to stabilize the economy on the basis of a social pact that froze prices and wages after a generalized wage increase. The stabilization policy resulted in the aforementioned rise in real income across the distribution, but it did not significantly alter the relative distribution of income that had prevailed up to the beginning of the decade. In 1975, the economy entered a recession, and by early 1976 the spectre of hyperinflation loomed (Gerchunoff and Llach, 1998).

Between 1976 and 1980 a series of policies were instituted -most of them of an orthodox nature- with a view to reining in the inflation and, at the same time, liberalizing the economy. The stabilization policy -whose main elements were a wage freeze and a programmed devaluation of the exchange rate, in a framework of repression of labour unions that also served the political interests of the military regimetriggered a collapse of real wages. The labour policy, meanwhile, included limitations on unemployment, imposed by the military authorities on the economic authorities and by the latter-informally-on businesses (Canitrot, 1981), aimed at minimizing social unrest in the environment of repression. As a result, unemployment in 1980 was scarcely $2 \%$.

The reforms of the 1970s included a substantial liberalization of trade $e^{44}$ and of the capital account of the balance of payments, coupled with deregulation of the internal financial market (figure 7). These reforms were considered essential components of the stabilization program, which was founded on the monetary approach to the balance of payments. One of their consequences was a substantial appreciation of the exchange rate which, combined with the reduction

cash income earned nationally but not declared or captured by the EPH, retained earnings from local businesses and income received as returns on household assets placed abroad.

${ }^{44}$ Although relatively moderate (in view of the redundancy of existing tariffs) and gradual: the liberalization process provided for tariff reductions of around 50\%, with differential treatment for basic industries, to be completed by 1984 (Canitrot, 1993). 
FIGURE 7

Argentina: Evolution of structural reforms

(Standardized indices between 0 and 1 )

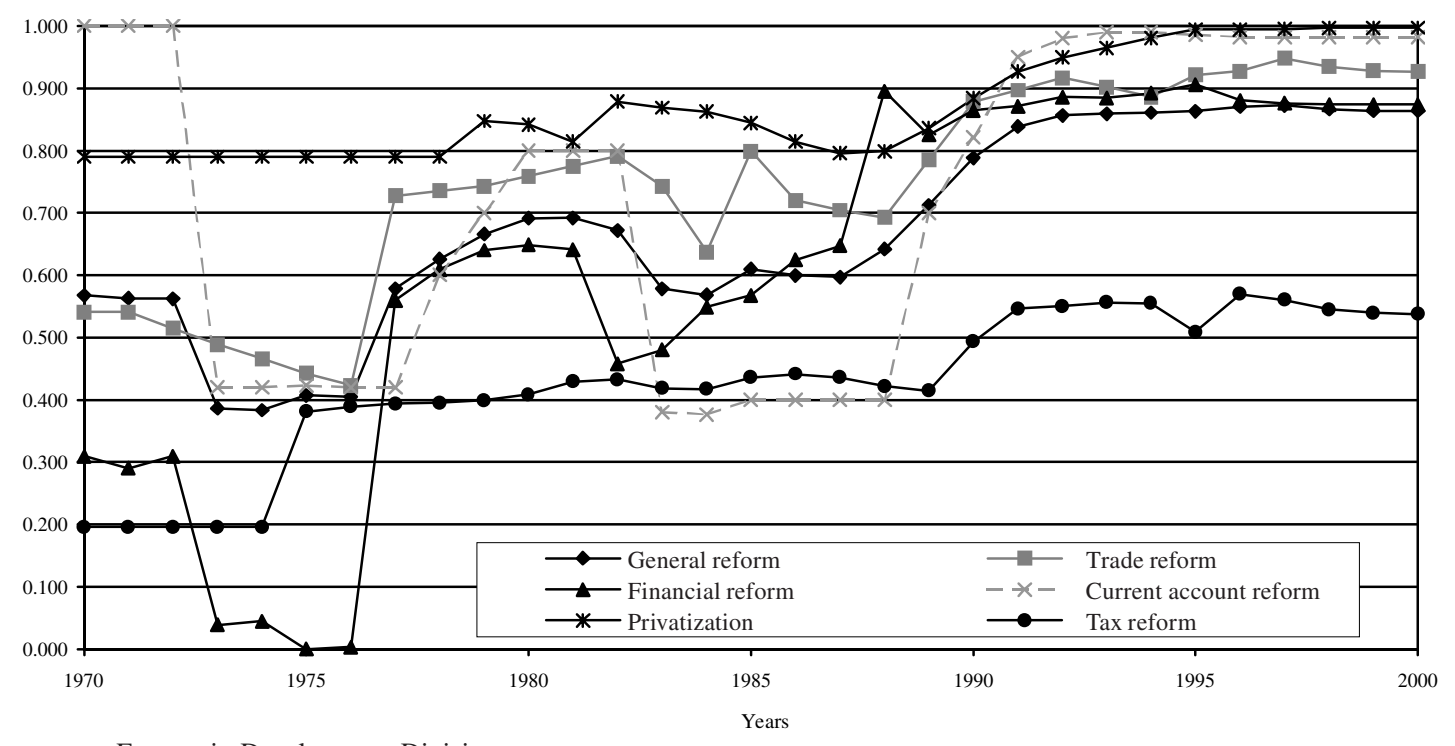

Source: ECLAC, Economic Development Division.

of tariffs, greatly reduced protection for domestic activity. Another consequence was an expansion of economic activity through external borrowing (Canitrot, 1993), together with hypertrophy of financial activity. The reduction of tariffs for capital goods by almost half, coupled with a $20 \%$ rise in the value of the currency, lowered the value of investment, although the high real levels of active interest rates (25\% on average) exerted an opposing effect. In addition, businesses benefited from modification of labour union relations that worked to their advantage and from the suppression of employer contributions to the pension system -at least until they were affected by the acceleration of inflation and the contraction of the market owing to competition from imported substitutes.

The investment made under these conditions entailed a process of productive transformation. In industry -where the volume of production shrank 20\%, reducing the sector's share of output by almost four points- the metalworking and electric industries lost ground to industrial commodities manufactured from natural resources and to traditional regional industries, aided in both cases by tax exemptions. In general, vertical integration tended to increase as a means of retaining qualified personnel and thus avoiding retraining costs ${ }^{45}$ (Katz and Kosacoff, 1989).

${ }^{45}$ This attitude revealed the belief that the future would bring a revival, not a transformation.
In these circumstances, it is not surprising that wage inequality grew, as did the rewards to education. Businesses applied a strategy of sheltering their most highly qualified staff from inflation, in order to retain and motivate them, while the least-skilled personnel -who now lacked union protection - fell behind, though not so far as to become unemployed. Moreover, during this period, there was a significant increase in the number of self-employed workers, who, possessing relative freedom to set prices in a context of high inflation and lack of wage security, were better able to protect their real incomes ${ }^{46}$ (table 9).

\section{The decade of crisis}

Argentina's economic policy underwent a number of ups and downs during this decade, responding, but also contributing, to the macroeconomic volatility. The monetary approach to the balance of payments was abandoned in 1981. In 1982, the contraction of external financing, the fall in the export prices and high international interest rates combined to create a critical situation that led to closing of the country's markets to imports and a de facto moratorium on foreign debt

${ }^{46}$ Although the most informal segment of these contingents may have changed categories as an alternative to unemployment, this appears to have occurred in only a minority of cases, owing to the labour market situation. 
TABLE 9

Greater Buenos Aires: Evolution of real mean income from principal occupation, by education level

(Employed workers with a single occupation who work 35 hours or more a week.

Percentage change between beginning and end of period)

\begin{tabular}{|c|c|c|c|c|c|c|}
\hline & 1974-1980 & 1980-1986 & 1986-1990 & 1990-1994 & 1994-1997 & $1997-2000$ \\
\hline \multicolumn{7}{|l|}{ All workers } \\
\hline Primary level not completed ${ }^{\mathrm{a}}$ & -19.4 & -14.2 & -31.0 & 25.4 & -16.7 & 0.5 \\
\hline Primary level completed & -18.5 & -13.0 & -36.8 & 24.4 & -12.5 & -3.5 \\
\hline Secondary level not completed & -21.3 & -7.0 & -35.9 & 21.9 & -19.0 & -3.2 \\
\hline Secondary level completed & -9.4 & -14.0 & -41.3 & 32.4 & -10.5 & -1.4 \\
\hline University level not completed & 4.5 & -18.4 & -30.1 & 29.6 & -23.8 & 0.7 \\
\hline University level completed & 9.5 & -14.9 & -30.7 & 10.3 & -1.4 & 3.3 \\
\hline \multicolumn{7}{|l|}{ Wage-earners } \\
\hline Primary level not completed ${ }^{\mathrm{a}}$ & -27.7 & -9.4 & -33.9 & 27.7 & -5.5 & -7.5 \\
\hline Primary level completed & -25.4 & -8.8 & -35.4 & 24.2 & -12.9 & -0.7 \\
\hline Secondary level not completed & -25.6 & -7.4 & -28.9 & 14.0 & -20.1 & -0.9 \\
\hline Secondary level completed & -16.8 & -17.4 & -36.7 & 22.1 & -4.4 & -1.9 \\
\hline University level not completed & 4.8 & -21.1 & -30.3 & 21.9 & -18.5 & 0.0 \\
\hline University level completed & 2.6 & -24.8 & -23.3 & 15.6 & -8.0 & 9.6 \\
\hline \multicolumn{7}{|l|}{ Non-wage-earners } \\
\hline Primary level not completed ${ }^{\mathrm{a}}$ & -1.2 & -19.3 & -44.1 & -5.2 & -35.6 & 164.0 \\
\hline Primary level completed & -15.2 & -4.2 & -47.9 & 20.6 & -8.1 & 102.4 \\
\hline Secondary level not completed & 20.3 & -9.8 & -48.6 & 34.7 & -12.5 & 100.9 \\
\hline Secondary level completed & 2.7 & -5.1 & -25.0 & 52.8 & -17.8 & 42.9 \\
\hline University level not completed & 22.8 & 1.1 & -39.7 & 42.8 & -34.7 & 46.7 \\
\hline University level completed & -13.2 & $\ldots$ & $\ldots$ & 5.1 & 10.7 & 14.9 \\
\hline
\end{tabular}

Source: Developed by the authors on the basis of data from the EPH.

${ }^{a}$ Includes persons with no formal schooling.

payments. The defeat in the Malvinas war sealed the fate of the military regime. The constitutional government that came to power in 1983 tried initially to continue the expansive wage policy initiated in the waning days of military rule and negotiate a political solution to the debt crisis. By around 1984, the trends of trade liberalization, capital account liberalization and financial reform had reversed (figure 7). In 1985, the Alfonsín administration succeeded in reaching an agreement with the International Monetary Fund (IMF) and renegotiating the external debt, adopting a heterodox program of stabilization that froze prices at previously adjusted relative levels and laid out a plan for reducing the fiscal deficit, establishing the rule that currency emission would not be used as a means of financing the deficit. By around the third quarter of 1986, GDP had recovered to 1980 levels, but inflation had also begun to accelerate again. Although employment had reached a new high, unemployment continued to grow, while real wages were shrinking (table 1).

In 1987, a succession of political problems, the subsequent drop in external prices and the upsurge in inflation necessitated the introduction of a new stabilization program, with external support made contingent on reforms (among them a tariff reduction). The anticipated electoral victory of the Peronists, with their program of populist measures and unilateral moratorium, prompted a sharp decline in the value of the currency in early 1989, which triggered hyperinflation and accentuated the recession that had begun more than a year earlier.

Although the new government's announcement of its plans for liberalization, privatization and fiscal austerity calmed the uncertainty and slowed inflation, steady currency appreciation and the use of domestic credit to finance the tax deficit led to a second bout of hyperinflation in early 1990. This was overcome with

INCOME DISTRIBUTION IN ARGENTINA, 1974-2000 • OSCAR ALTIMIR, LUIS BECCARIA AND MARTIN GONZALEZ ROZADA 
a monetarist strategy, a truce with external creditors and a "cash" fiscal policy. The abandonment of the latter and the renewed use of domestic credit by fiscal authorities again raised the threat of hyperinflation.

In this conflictive period, the economy suffered from a lack of consistent economic policy and, at the same time, from too many short-lived policies that ended in failure, thereby generating even more instability. As a result, the system of incentives underwent radical variations, and investment weakened and became unfocused, leading to fragmentation of the earlier process of productive transformation. Argentina did not return to the path of liberalization and deregulation until 1988 (figure 7).

In the first part of the decade, the weakness in the productive sector began to manifest itself in the growth of unemployment and the increase in informal-sector employment. However, the stabilization of 1986 led to some improvement in real wages. In the new context of labour union freedom, the least-skilled wage-earners experienced the greatest relative growth in wages, which resulted in a smaller wage differential by educational level and lower relative earnings for self-employed workers. In the later context of escalating inflation, workers at all skill levels experienced a relatively even deterioration in real wages (table 9). Hence, as the decade of crisis drew to a close, the rewards to education and the dispersion of hourly earnings were not substantially different from what they had been at the beginning of the decade, thanks to a demand for labour hesitant without significant biases.

\section{The reforms of the 1990 s and the convertibility regime}

\section{a) Macroeconomic policy and trends}

In early 1991, Argentina adopted a strategy of liberal reforms and quick disinflation, establishing a system of convertibility, pegging the national currency to the United States dollar, and imposing strict rules to prevent monetary financing of the fiscal deficit. Tax reforms and rapid privatization of public enterprises were announced, controls on the movement of capital were lifted and trade was liberalized considerably, thus dramatically accelerating a process that had been developing slowly since the end of the previous decade (figure 7). In addition, taxes on exports and quantitative restrictions on imports were eliminated and tariffs were reduced significantly with the aim of establishing a system of neutral incentives between exports and imports.
Inflation fell rapidly, dropping to a monthly rate of around $1 \%$ within a few months. The recovery of real wages and the increase in consumer credit spawned growth in demand. At the same time, tax collection doubled in real terms and the fiscal deficit began to abate. Macroeconomic stability and structural reforms inspired investor confidence and combined with external factors to generate a massive inflow of voluntary private capital, in the framework of the new liberal system of capital movement.

As a result of the combined effect of the sudden liberalization of trade and the fixation of the exchange rate, industrial prices behaved like those of fully tradable goods, lagging behind prices for the nontradable goods. This evolution of relative prices, in the context of a fixed rate of exchange, led to a considerable appreciation of the currency between 1991 and 1994. In addition, interest rates fell drastically, with passive rates turning negative in real terms for several months.

Around 1994, the influx of capital slowed, whereas the current account deficit continued to grow. Some sectors of production showed early symptoms of recession. But the possibilities for a gradual contraction that had been hinted at were brutally cut off by the effects of the Mexican crisis, which sparked an abrupt contraction of credit, together with a deterioration of expectations, as a result of which internal demand plunged. The collapse of the program was avoided through the introduction of monetary measures, and by the third quarter of 1996 GDP had recovered the level of the corresponding period in 1994. The increase in aggregate demand translated into a significant expansion of imports. However, with the increase in the value of exports, the balance-of-trade equilibrium was maintained and the renewed inflow of capital easily financed the current account deficit. In 1997, growth was vigorous (8\%) in an environment of absolute price stability.

The simultaneous deterioration of the current account of the balance of payments and of fiscal accounts made macroeconomic sustainability even more dependent on capital inflow. Under these conditions, the reduction of capitals flows as a consequence of the Russian crisis triggered a credit contraction that marked, in 1998, the beginning of a decline in activity level, which continued and exacerbated the dependence on increasingly elusive external capital. In 1999, the Menem administration relaxed fiscal policy in an effort to obtain political support for its continuity. Faced with a rising tax deficit and endeavouring to assure the credibility of its policies

INCOME DISTRIBUTION IN ARGENTINA, 1974-2000 • OSCAR ALTIMIR, LUIS BECCARIA AND MARTIN GONZALEZ ROZADA 
vis-à-vis investors, the new government resorted to contractive fiscal measures in early 2000. But the erosion of confidence continued, hastened by the perception of brewing political conflict, in a process that would culminate at the end of 2001 in the collapse of the banking system and the abandonment of the convertibility regime.

\section{b) Influence on labour performance and income distribution}

The evolution and characteristics of labour demand during the 1990s, in the framework of incentives established under the new economic order and the convertibility regime, had distributive impacts, both through their effect on the level of full-time employment, underemployment and the resulting unemployment and through their influence on the intensity of demand for workers with various qualifications.

Beyond the cyclical behaviour, ${ }^{47}$ the two expansive phases of the decade, which culminated, respectively, in 1994 and 1997/1998, represented two different stages in the behaviour of aggregate demand for labour. In the first, the recovery and later growth of GDP (at an annual rate of $8.7 \%$ ) was based almost entirely on increases in productivity, while total employment increased slowly (at a rate of $0.8 \%$ annually) and industrial employment contracted (table 10). As was mentioned above, the considerable increase in productivity should be attributed partly to the renewal of economic activity, in the new context of stability and capital inflows, and partly to the displacement of the production frontier with technical change. This displacement, in turn, resulted from investments facilitated by the liberalization process, exchange rate appreciation and external financing, as well as reorganization of work processes with little investment -both strategies motivated by the quest for greater international competitiveness in the new context (Altimir and Beccaria, 2000b).

During the second expansive phase, ${ }^{48}$ on the other hand, GDP growth (at an annual rate of $8 \%$, close to that of the previous phase) was supported in similar proportions by the expansion of employment and by increases in productivity, although in industry it was

\footnotetext{
${ }^{47}$ Described by Damill, Frenkel and Maurizio (2002), among others.

48 The upward phase of the cycle is considered to have run from the start of the recovery following the tequila episode in the third quarter of 1995 to the fourth quarter of 1997 (although this phase lasted until mid-1998, when the recession began to develop).
}

the productivity growth that continued driving the process and constraining job creation (table 10).

The aforementioned study by Damill, Frenkel and Maurizio (2002) concurs with these assessments in the sense that their econometric results suggest that the contractive period during which full-time employment adjusted to the new environment was completed in 1996. However, in the case of manufactured goods, that adjustment appears to have continued beyond 1996.

The establishment and deployment of the new economic order and macroeconomic regime had repercussions on the evolution of the demand for labour, primarily through investment. The latter reached a peak in the 1990s -supported by the flow of external capitalin response to the stabilization of the economy, the new rules, the expansion of aggregate demand and the change in relative prices which favoured capital accumulation (Ramos and Martínez, 2000). The reduction of tariffs and the appreciation of the exchange rate brought about by the new macroeconomic regime radically changed the relative prices of labour and capital: while industrial wages doubled in dollars, the value of capital goods plummeted. ${ }^{49}$ This encouraged a process of technological updating that had been postponed owing to the weakness of investment in the 1980s, and provided an incentive for the substitution of capital for labour across the economy, which brought more intensive use of capital in production and a reduction of employment-output elasticity. ${ }^{50}$ At the same time, the opening up of imports, together with the rise in exchange rates, led Argentine producers to attempt to increase their international competitiveness on the domestic market by substantially improving productivity $^{51}$ and seeking savings on labour.

However, there was also some elimination of jobs associated with the institution of the new order. The liberalization of trade resulted in disinvestments -with a consequent loss of jobs- by provoking the closing of businesses and plants, especially small and mediumsized industries. Moreover, part of the productivity gains were obtained by means of reductions in personnel as

\footnotetext{
${ }^{49} \mathrm{To}$ an extent that minimized the effect of the rise in real interest rates, which with the advent of price stability turned positive.

${ }^{50}$ Employment-output elasticity between the first quarter of 1990 and the fourth quarter of 1994 was 0.16 , compared to 0.37 between mid-1985 and the third quarter of 1987. In contrast, during the second expansive phase, between the first quarter of 1995 and the fourth of 1997, elasticity was 0.48 (Altimir and Beccaria, 2000b). ${ }^{51}$ In the export sector, on the other hand, although investments were also favoured by the price of capital, currency appreciation created a disincentive.
} 
TABLE 10

Argentina: Evolution of GDP, employment and productivity in the 1990s

(Mean rate of yearly change between first and last period)

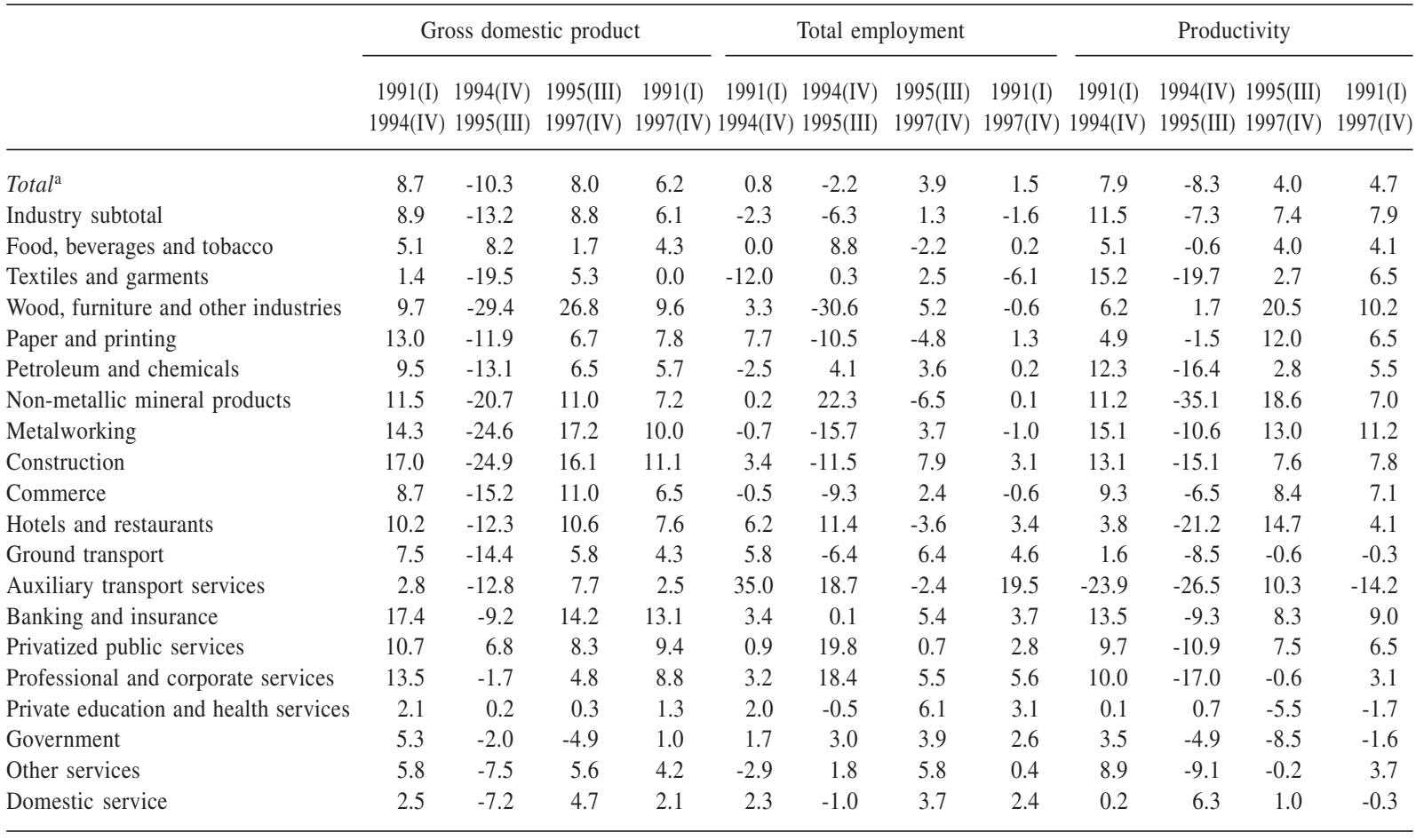

Source: Developed by the authors on the basis of data from the EPH.

a Excludes primary activities.

work processes were rationalized, without additional investment in fixed capital. Workers were also let go from privatized enterprises, though those job losses explain only a small part of the growth registered in total unemployment. ${ }^{52}$

Investments in new technology presumably also biased the demand for labour in favour of the most highly skilled workers, at least in the case of those whose skills complemented the new capital (or the organizational structures) involving the use of more recent technology. This bias is apparent, at the aggregate level, not only in employment, but also in wages, although more so in the second phase of expansion than in the first.

${ }^{52}$ Tentative estimates indicated that around 150000 jobs were lost in public enterprises between 1991 and 1995. That figure amounts to $10 \%$ of the unemployment registered only in the cities covered by the EPH (Altimir and Beccaria, 2000b).
These indirect effects -not all intentional- of the economic policy on the labour and distributive situation are only part of the story, however. Another important aspect of the role played in this area by economic policy is the extent to which it has been able to sustain the level of activity and, therefore, the level of demand for employment and productivity. The reforms to the economic order and the macroeconomic regime of convertibility were highly successful in terms of stabilizing the economy, reviving investment and engendering economic recovery and growth, until the tequila crisis. The country's ability, with international help, to deal effectively with that crisis restored confidence in a macroeconomic regime whose inflexibility -though originally its strength- was revealing itself to be a weakness.

The fixed parity not only combined with overvaluation of the currency to limit the competitiveness of exports, it also robbed the

INCOME DISTRIBUTION IN ARGENTINA, 1974-2000 • OSCAR ALTIMIR, LUIS BECCARIA AND MARTIN GONZALEZ ROZADA 
stabilization policy of a key instrument and -together with the dollarization of credit- made the foreign exchange policy the frame of reference for contracts and left domestic credit and the activity level wide open to external shocks (Heymann, 2000). The fiscal equilibrium suffered as a result of growing tension between the need to offset the foreign exchange policy with tax cuts aimed at boosting competitiveness, stimulate employment and address growing social and

\section{VIII}

\section{Conclusions}

The persistently upward and largely structural trend of inequality in family income has been determined mainly by labour market forces, which have been reflected in the structure of wages, in the evolution of the labour supply and in the imbalances between supply and demand, giving rise, inter alia, to growing unemployment. However, income inequality has been influenced by various combinations of factors, which have changed from period to period.

As a stylized picture, the deterioration of the distribution of well-being in the last quarter-century took place in four phases: (i) in the 1970s, through the real reduction of wages and their relative dispersion, in the context of an orthodox adjustment (but with restriction on unemployment) and a liberalization process; (ii) in the 1980s, through the impact of growing unemployment due to successive crises, with little restructuring and a certain resilience of the wage structure; (iii) in the first phase of expansion in the 1990s, under a new economic order, more open to the exterior, in a context of declining State activism and price stability, through the growing unemployment generated by inelastic demand for labour -as a consequence of the restructuring of production- and a labour supply enlarged by greater desire for participation; and (iv) in the last phase of expansion, through greater wage inequality.

Earnings also showed a trend towards increasing inequality -though to a lesser extent than family income- between 1974 and 2000, but as a result of two waves of worsening: one in the second half of the 1970s and the other in the 1990s. In both instances, that increase was a decisive factor in the increase registered by the concentration of household income. political demands. The rising external public debt, to close the fiscal equation, formed the prelude to the situation that ultimately led to the collapse of late 2001. There is little doubt that the tenacious adherence to a regime that was dangerously vulnerable and would prove ultimately unsustainable was largely responsible for the social crisis that erupted after its collapse, though the analysis of that phenomenon is beyond the scope of this article.
The two liberalization processes -the attempt of the 1970s and the reform of the 1990s-appear to have brought about a restructuring of employment that had negative distributive consequences. In the 1970s, the strong drop in real wages enhanced competitiveness but also substantially widened the wage gap between workers at different skill levels and, at the same time, maintenance of the employment level curtailed the productive restructuring. The new economic order of the 1990s, on the other hand, utilized liberalization as an instrument for a profound restructuring, allowing unemployment to reach unprecedented levels at a time of expansion. In the first phase, the restructuring -mainly in industry- focused on rationalizing employment and saving labour, with the consequent rise in unemployment, while the bias arising from the demand for skilled labour had a relatively lesser importance. In the second phase, the roles were reversed: the bias in favour of higher skill levels in the demand for labour translated into an intensification in wage differences, whereas the employment level was maintained and its elasticity increased, with smaller increases in productivity. This may indicate that the restructuring had, within a short time, enabled a recovery of most of the technological lag, at least from a medium-term business perspective.

The stylized history of the distributive deterioration presented here can thus be interpreted as one dimension of the long and uncertain process of transformation from a post-war style of development -characterized by import-substituting industrialization led by the Stateto a more functional style of integration into the international economy and globalization processes in which market forces prevail. 
From this standpoint, the two attempts at reforming the economic order involved strategies for stabilization, deregulation and liberalization, aimed at transforming the style of development. However, the concrete aspects of the anti-inflationary policy had a decisive impact on the process of productive transformation. The wage freeze in the 1970s favoured competitiveness but also deepened wage differences. The fixed exchange rate of the 1990s dramatically intensified the liberalization of imports, artificially lowered the price of capital goods, raised dollar wage costs and hampered exports, particularly of labour-intensive products -all incentives against increased employment. In the process of the 1990s, the quest for labour savings generally seems to have taken precedence over the demand for more qualified labour, although that demand did nevertheless increase the wage differential.

However, it might be assumed that -despite these distortions which exaggerated the negative effects of both the first attempt at liberalization and the most recent reform of the economic order-greater economic freedom enabled the development of market forces that guided investment towards a production pattern that was more integrated into the international economy. That transformation process, however, was guided only by market signals, since the design of the reforms did not include industrial or technological policy mechanisms that would have contributed to the development of dynamic comparative advantages.

The new economic model led, in addition to currency appreciation and the ultimate collapse of the macroeconomic regime that accompanied the institutional reforms and gave rise to the current crisis, to a decline in the employment elasticity of growth, thereby generating more structural unemployment, and a larger wage gap between workers at different skill levels. Nevertheless, against this backdrop, there is room for public policy to attempt, on the one hand, to guide productive forces towards a more dynamic integration into the international economy, in a way that will create quality jobs and raise wages across the board, and on the other, to develop effective systems of social protection to address the numerous situations of vulnerability that emerge from the new style of development.

(Original: Spanish)

APPENDIX

\section{Microsimulation model and methodology}

The methodology is based on estimation of a polychotomous or discrete model of individual labour force participation. In this model, each individual of working age may fall into one of the following three mutually exclusive categories: (1) employed, (2) unemployed or (3) outside the labour force. It is assumed, with no loss of generality, that there are $N_{1}$ employed individuals, $N_{2}$ unemployed individuals and $N_{3}$ non-participants in the labour force, such that $N=N_{1}+N_{2}$ $+N_{3}$.

Assume that $V_{i j}$ is the maximum utility achieved by an individual $i$ who chooses alternative $j$. If $V_{i j}$ is linear,

$$
V_{i j}=\delta_{j}^{\prime} x_{i}+u_{i j}, \quad i=1,2, \ldots, N
$$

where $x_{i}$ is a vector of the characteristics of the individual that capture all information relevant to the selection of the alternative for which $V i j$ is the maximum, and $u_{i j}$ is an error term that is assumed to be independent and identically distributed with a double exponential or Gumbel distribution.

For each of the three alternatives, there is a utility function like [1], and the alternative $s(s=1,2,3)$ is selected only if it offers the greatest utility, i.e.,

$$
V_{s}>\max _{j \neq s} V_{j}
$$

defining

$$
\pi_{s}=\max _{j \neq s} V_{j}-u_{s}
$$

The alternative $s$ will be selected only if $\delta_{s}^{\prime} x_{s}>\pi_{s}$. As $u_{i j}$ is distributed independently and identically with a Gumbel distribution and if $X$ is a vector of exogenous variables $\left(X=\left[x_{1}, x_{2}{ }^{\prime}, \ldots, x_{N}^{\prime}\right]^{\prime}\right)$, the distribution $\mathrm{F}\left(\pi_{s}\right)$ of $\pi_{s}$ is

$$
F\left(\pi_{s}\right)=\exp \left(\pi_{s}\right) /\left[\exp \left(\pi_{s}\right) \underset{j \neq s}{+3} \exp \left(\delta_{j}^{\prime} X\right)\right],
$$

and the probability that alternative $s$ will be selected is:

$$
P s=\frac{\exp \left(\delta_{j}{ }^{\prime} X\right)}{\sum_{j \neq s}^{3} \exp \left(\delta_{j}{ }^{\prime} X\right)}
$$

which is the conditional logit model (see McFadden, 1974) estimated by means of the maximum likelihood method. ${ }^{53}$

$$
\begin{aligned}
& { }^{53} \text { The probabilities for each of the three alternatives are: } \\
& \qquad(s=1)=\frac{e^{x \delta_{1}}}{e^{x \delta_{1}}+e^{x \delta_{2}}+e^{x \delta_{3}}} \quad P(s=2)=\frac{e^{x \delta_{2}}}{e^{x \delta_{1}}+e^{x \delta_{2}}+e^{x \delta_{3}}} \\
& P(s=3)=\frac{e^{x \delta_{3}}}{e^{x \delta_{1}}+e^{x \delta_{2}}+e^{x \delta_{3}}}
\end{aligned}
$$

This model, however, is not identified in the sense that there is more than one solution for $\delta_{1}, \delta_{2}$ and $\delta_{3}$ that has the same probabilities for $s=1, s=2$ and $s=3$. To identify the model, the usual procedure of selecting one of the three alternatives as the base 
For microsimulations, it is also necessary to assign labour incomes to those individuals in the working-age population who do not have earnings because they are unemployed or inactive, in case they are selected to change activity category and also in order to estimate the effects of changes in rewards to various socio-demographic characteristics (see below).

If the individual is employed, his/her labour income (in logarithms) is given by:

$$
W_{1 i}=\beta_{1}^{\prime} Z_{1 i}+\varepsilon_{1 i}, \quad i=1,2, \ldots, N_{1}
$$

where the subindex $i$ refers to $i^{\text {th }}$ individual, $Z_{1 i}$ is a vector of exogenous characteristics and $\varepsilon_{l i}$ is a random term.

In equation [4] there is sample selection bias if the errors $\varepsilon_{i}$ and the disturbances $u_{i j}$ in [1] are correlated. This problem is corrected by using the method proposed by Lee (1983), which makes it possible to transform the polychotomous model of participation into a binary decision problem, as indicated above.

If $\Phi$ denotes the function of the standard normal distribution, the transformation $J=\Phi^{-1} F$ is strictly increasing and the transformed random variable $\pi_{s}^{*}$ [equation 2], where $\pi_{s}^{*}=J\left(\pi_{s}\right)$, will also be a standard normal variable. Hence, the alternative $s$ will be selected only if $J\left(\delta_{s}{ }^{\prime} X\right)>\pi_{s}{ }^{*}$. This specification implies that, provided alternative $s$ is selected,

$$
\begin{gathered}
W_{s}=\beta_{s}^{\prime} Z_{s}-\rho_{s}\left(\phi\left(J\left(\delta_{s}^{\prime} X_{s}\right)\right) / F\left(\delta_{s}^{\prime} X_{s}\right)\right)+\xi_{s} \\
=\beta_{s}^{\prime} Z_{s}+\omega_{s},
\end{gathered}
$$

where $E\left(\xi_{\mathrm{s}} /\right.$ s selected $)=0, \phi$ is the density of a standard normal and $X_{s}$ is a partition of $X$ (see Lee, 1983).

Hence, equation [5] is estimated for $s=1$, using the estimators for the parameters $\delta$ calculated from the logit model. Replacing those estimators in [5], in the second stage it is estimated that

category was followed-i.e., making the coefficient for that category zero (in this exercise, the base category was that of individuals who are non-participants in the labour force). Multiplying and dividing these probabilities by $\mathrm{e}^{-\mathrm{X} \delta_{3}}$ yields:

$$
\begin{gathered}
P(s=1)=\frac{e^{x\left(\delta_{1}-\delta_{3}\right)}}{e^{x\left(\delta_{1}-\delta_{3}\right)}+e^{x\left(\delta_{2}-\delta_{3}\right)}+1} \quad P(s=2)=\frac{e^{x\left(\delta_{2}-\delta_{3}\right)}}{e^{x\left(\delta_{1}-\delta_{3}\right)}+e^{x\left(\delta_{2}-\delta_{3}\right)}+1} \\
P(s=3)=\frac{1}{e^{x\left(\delta_{1}-\delta_{3}\right)}+e^{x\left(\delta_{2}-\delta_{3}\right)}+1}
\end{gathered}
$$

In other words, the estimated coefficients can be interpreted as the effect of the difference between the actual coefficient of the category and the coefficient of the category selected as the base category over the probability. Thus, for example, the relative probability for employed workers compared with non-participants in the labour force is:

$$
\frac{P(s=1)}{P(s=3)}=e^{x\left(\delta_{1}-\delta_{3}\right)}=e^{x \beta}
$$

and the estimate of $\beta$ is the impact on relative probability.

$$
\text { [6] } \quad W_{1}=\beta_{1}^{\prime} Z_{1}-\rho_{1}\left(\phi\left(J\left(\hat{\delta}_{1} X_{1}\right)\right) / F\left(\hat{\delta}_{1}^{\prime} X_{1}\right)\right)+\widetilde{\xi}_{1} \text {. }
$$

The disturbances in equation [6] are heterocedastic and are correlated through the various sample observations. An asymptotically correct matrix of variances and covariances is constructed, utilizing a modification of the procedure followed by Lee, Maddala and Trost (1980). ${ }^{54}$

Based on this equation, it is then possible to assign a wage to those individuals of working age who are not earning a wage because they are unemployed or inactive, in case they are selected to change activity status. For that purpose, it is necessary to generate an error term for each of the individuals as if he/she were employed. As the residual of the wage equation, $\omega_{1}$, is not observed for these individuals, it is generated conditioned on what is observed. This is done by generating $\psi_{1}$ from a standard normal distribution and then calculating:

$$
\hat{\omega}_{2}=-\hat{\rho}_{1}\left(\phi\left(J\left(\hat{\delta}_{1}^{\prime} X_{2}\right)\right) / F\left(\hat{\delta}_{1}^{\prime} X_{2}\right)\right)+\hat{\sigma} \xi_{1} \psi_{1}
$$

The first term in equation [7] is the expected value of $\omega_{2}$, conditioned on the person's being employed. The estimate of the standard deviation of $\xi_{1}\left(\sigma \xi_{1}\right)$ is obtained from the estimate of the quadratic minimum of [6]. Therefore, wages or earnings for unemployed and inactive individuals are calculated as

$$
\widehat{W}_{s}=\hat{\beta}_{1}^{\prime} Z_{s} \hat{\omega}_{2}
$$

where $s=2,3$.

\section{Microsimulation procedures}

The probabilities obtained from estimating the polychotomous model of participation and the estimated coefficients for the labour income functions for year $t$ are used to assess the effect on per capita household income distribution, between that year and $t+k$, of changes in economic participation, unemployment, educational attainment of the labour force and the earnings of human capital. To that end, several counterfactual populations were simulated, replicating sequentially and cumulatively in the population for year $t$ the values of the variables registered in $t+k$. The effect of changes in those variables is quantified by comparing the indicators of inequality for the actual income distribution with those for the distributions computed using the counterfactual populations.

\section{i) Effect of change in the participation rate}

Estimating the polychotomous model of participation in year $t$ makes it possible to obtain, as explained above, the marginal probabilities that each individual will be employed $\left(\mathrm{P}_{t, 1)}\right.$, unemployed $\left(\mathrm{P}_{t, 2}\right)$ or outside the labour force $\left(\mathrm{P}_{\mathrm{t}, 3}\right)$.

The next step is to rank the individuals in the population for year $t$ according to $\mathrm{P}_{\mathrm{t} \text {,in }}$, the probability of being active (which is the sum of $\mathrm{P}_{t, 1}$ and $\mathrm{P}_{t, 2}$ ) and $\mathrm{P}_{\mathrm{t}, 1}$ such that the first

\footnotetext{
${ }^{54}$ For a more detailed explanation of this correction procedure, see González Rozada and Menéndez (1999).
} 
places in the sample are occupied by those individuals with the greatest probability of belonging to the labour force. If $f \%$ is the proportion of individuals who participate in the labour force in year $t+k$, this ranking will make it possible to identify the overall $f \%$ of individuals in the population for year $t$ who would be labour force participants. Thus, the participation rate for year $t+k$ is substituted for the rate for year $t$. The $f \%$ of the population for year $t$ who would be labour force participants is ranked (by $\mathrm{P}_{\mathrm{t}, 1}$ ) such that those individuals with the greatest probability of being employed, based on their characteristics in $t$, appear first. Hence, by identifying in this ranking the proportion $(e \%)$ of persons employed in year $t$, the members of the active population are classified as employed or unemployed.

This counterfactual method of organizing the population for year $t$ ensures that the $f \%$ of the population with the greatest probability of belonging to the labour force, given their characteristics in that year, would actually have belonged to that population and that the $e \%$ of the active population for year $t$ with the greatest probability of being employed would have been employed.

Once the counterfactual population has been organized, labour income must be assigned. For individuals whose activity status does not change, nothing is modified: for those who are unemployed or inactive, a wage of zero is registered, and for those who are employed, their declared wage is used. For those who go from being unemployed or inactive in $t$ to being employed in the counterfactual population, the income obtained using equation [8] is assigned.

Family income and the indicators of its distribution are recalculated using these individual earnings. By comparing various measures of inequality for the original distribution in year $t$ with the distribution computed using the counterfactual population it is possible to quantify the effect of the change in the participation rate between $t$ and $t+k$ on the distribution of family income.

\section{ii) Effect of change in the unemployment rate}

To capture the additional effect of the change in unemployment rate (given the change in the participation rate) between $t$ and $t+k$, the same procedure as that described in section (i) is used, i.e., first the counterfactual population is re-ranked using $\mathrm{P}_{\mathrm{t}, \text { in }}$ and then using $\mathrm{P}_{\mathrm{t}, 2}$ such that individuals with the least probability of being unemployed, given their characteristics in year $t$, appear first. If $d \%$ is the proportion of unemployed individuals in $t+k$, the new simulated population obtained identifies the group of individuals who would have been unemployed in $t$ if the unemployment rate in $t+k$ had prevailed. Once the counterfactual population has been simulated, earnings are assigned, either by maintaining the actual income registered or - for those whose status changes - the wage obtained using equation [8]. By comparing the resulting family income distribution (which has been simulated using the activity and unemployment rates for $t+k$ ) with the counterfactual distribution calculated in the section (i) above (which has been simulated using the participation rate for $t+k$ and the unemployment rate for $t$ ), the effect of the change in unemployment can be assessed.

\section{iii) Effect of change in the educational structure of the employed population}

The first step was to calculate the proportion of individuals with a complete or incomplete primary education (p\%), complete or incomplete secondary education (s\%) and complete or incomplete university education $(u \%)$ in the population for year $t+k$. The second step was to rank the counterfactual population calculated in section (ii) within each activity category (employed, unemployed, inactive), with the group having a primary education appearing first, followed by those with a secondary education and, finally, those with a university education. The individuals in the first of these strata (employed people) were randomly ranked within each educational category, utilizing the random number generated for each person in order to assign the counterfactual wages. Then, selecting from this ranking the proportions of people with primary education ( $\mathrm{p} \%)$, secondary education (s\%) and university education $(\mathrm{u} \%)$ in $t$ $+k$, the counterfactual population that reflects the educational structure of the employed population for $t+k$ was constructed.

The next step was to assign earnings to the individuals in this population who changed educational category. These individuals were assigned an income - either declared or calculated using equation [8] - equivalent to multiplying the earnings they had by the ratio, in year $t$, between the mean income for their new and old educational categories. Once the incomes of the counterfactual population have been calculated, it is possible to calculate family income and its distribution. By comparing the latter with the simulated distribution from section (ii), the effect of changes in educational structure on the distribution of family income can be appraised.

\section{iv) Effect of changes in earnings}

The earnings of the counterfactual population obtained in section (iii) were modified such that they reflected the structure of earnings for year $t+k$. Each individual was assigned an income generated using equations [6] and [8], but with the estimated coefficients of both equations for year $\mathrm{t}+\mathrm{k}$. All members of the population thus have the earnings that they would have received in $\mathrm{t}+\mathrm{k}$, given their socio-demographic characteristics. For those who changed educational category, this new earning is multiplied by the ratio, in year $t+k$, between the mean income for their new and old educational categories. After thus modifying the earnings of the individuals, it was possible to calculate the distribution of family income in this counterfactual population. By comparing that distribution with the distribution for the counterfactual population obtained in (iii), the additional effect of changes in earnings structure on income distribution can be evaluated. 


\section{Bibliography}

Altimir, O. (1986): Estimaciones de la distribución del ingreso en la Argentina, 1953-1980, Desarrollo económico, vol. 25, No. 100, número extraordinario, Buenos Aires, Institute of Economic and Social Development (IDES).

Altimir, O. and L. Beccaria (1998): Efectos de los cambios macroeconómicos y de las reformas sobre la pobreza urbana en Argentina, in E. Ganuza, L. Taylor and S. Morley, Política macroeconómica y pobreza en América Latina y el Caribe, Santiago, Chile, United Nations Development Programme (UNDP)/Inter-American Development Bank (IDB)/Economic Commission for Latin America and the Caribbean (ECLAC).

(2000a): Distribución del ingreso en la Argentina, in D.

Heymann and B. Kosacoff (eds.), La Argentina de los noventa: desempeño económico en un contexto de reformas, Tomo I, Buenos Aires, Editorial Universitaria de Buenos Aires (EUDEBA)/ ECLAC office in Buenos Aires.

(2000b): El mercado del trabajo bajo el nuevo régimen económico en Argentina, in D. Heymann and B. Kosacoff (eds.), La Argentina de los noventa: desempeño económico en un contexto de reformas, Tomo I, Buenos Aires, EUDEBA/ ECLAC office in Buenos Aires.

(2001): El persistente deterioro de la distribución del ingreso en la Argentina, Desarrollo económico, vol. 40, No. 160, Buenos Aires, Institute of Economic and Social Development (IDES).

Bourguignon, F., M. Fournier and M. Gourgand (1998): Distribution, development and education: Taiwan, 1979-1994, paper presented at the Primer Taller de la Red sobre Desigualdad y Pobreza, Buenos Aires, Latin American and Caribbean Economic Association (LACEA) /IDB/World Bank.

Bourguignon, F., F. Ferreira and N. Lustig (2001): The microeconomics of income distribution dynamics: A comparative analysis of selected developing countries, paper presented at the Encuentro de la Sociedad Econométrica, Buenos Aires, unpublished.

Canitrot, A. (1981): Teoría y práctica del liberalismo. Política antiinflacionaria y apertura económica en la Argentina, 19761981, Desarrollo económico, vol. 21, No. 82, Buenos Aires, Institute of Economic and Social Development (IDES).

(1993): Inestabilidad y flujos de comercio en Argentina, 1978-1981, "Reformas de política pública", series, No. 2, LC/L.732, Santiago, Chile, ECLAC.

Damill, M., R. Frenkel and R. Maurizio (2002): Argentina: una década de convertibilidad. Un análisis del crecimiento, el empleo y la distribución del ingreso, Santiago, Chile, International Labour Office.
Frenkel, R. and M. González Rozada (1998): Apertura, productividad y empleo: Argentina en los años 90, "Documentos de economía" series, No. 9, Buenos Aires, Universidad de Palermo/ Centre for Studies on the State and Society (CEDES).

(2000): Tendencias de la distribución de ingresos en los años noventa, "Documentos de economía" series, No. 16, Buenos Aires, Universidad de Palermo/ Centre for Studies on the State and Society.

Gerchunoff, P. and L. Llach (1998): El ciclo de la ilusión y el desencanto. Un siglo de políticas económicas argentinas, Buenos Aires, Ariel.

González Rozada, M. and A. Menéndez (1999): The effect of unemployment on labor earnings inequality in Argentina, Princeton, New Jersey, Princeton University, unpublished.

Heymann, D. (2000): Políticas de reforma y comportamiento macroeconómico, in D. Heymann and B. Kosacoff (eds.), $L a$ Argentina de los noventa: desempeño económico en un contexto de reformas, Tomo I, Buenos Aires, EUDEBA/ ECLAC office in Buenos Aires.

Katz, J. and B. Kosacoff (1989): El proceso de industrialización en la Argentina: evolución, retroceso y prospectiva, LC/BUE/ G.104, Buenos Aires, ECLAC office in Buenos Aires.

Llach, J. and C. Sánchez (1984): Los determinantes del salario en la Argentina, Estudios, No. 29, Córdoba, Argentina, Instituto de Estudios Económicos sobre la Realidad Argentina y Latinoamericana (IEERAL).

Lee, L.-F. (1983): Generalized econometric models with selectivity, Econométrica, No. 48, Evanston, Illinois, The Econometric Society.

Lee, L., G.S. Maddala and R.P. Trost (1980): Asymptotic covariance matrices of two-stage Tobit methods for simultaneous equation models with selectivity, Econometrica, No. 48, Evanston, Illinois, The Econometric Society.

McFadden, D. (1974): Conditional logit analysis of qualitative choice behavior, in P. Zarembka (ed.), Frontiers in Econometrics, New York, Academic Press.

National Institute of Statistics and Censuses (INDEC), (several years): Encuesta Permanente de Hogares, Buenos Aires.

Ramos, A. and R. Martínez (2000): El proceso de inversiones en la economía Argentina. Impacto de las reformas de política y procesos de decisión ante un cambio de incertidumbres, in D. Heymann and B. Kosacoff (eds.), La Argentina de los noventa: desempeño económico en un contexto de reformas, Tomo I, Buenos Aires, EUDEBA/ ECLAC office in Buenos Aires. 